University of Nebraska - Lincoln

DigitalCommons@University of Nebraska - Lincoln

Faculty Papers and Publications in Animal

Science

Animal Science Department

February 2004

\title{
Genetic response to selection for weaning weight or yearling weight or yearling weight and muscle score in Hereford cattle: Efficiency of gain, growth, and carcass characteristics
}

\author{
R. M. Koch \\ University of Nebraska-Lincoln \\ L. V. Cundiff \\ Roman L. Hruska U. S. Meat Animal Research Center, USDA-ARS \\ K. E. Gregory \\ Roman L. Hruska U. S. Meat Animal Research Center, USDA-ARS \\ L. Dale Van Vleck \\ University of Nebraska-Lincoln, dvan-vleck1@unl.edu
}

Follow this and additional works at: https://digitalcommons.unl.edu/animalscifacpub

Part of the Animal Sciences Commons

Koch, R. M.; Cundiff, L. V.; Gregory, K. E.; and Van Vleck, L. Dale, "Genetic response to selection for weaning weight or yearling weight or yearling weight and muscle score in Hereford cattle: Efficiency of gain, growth, and carcass characteristics" (2004). Faculty Papers and Publications in Animal Science. 206.

https://digitalcommons.unl.edu/animalscifacpub/206

This Article is brought to you for free and open access by the Animal Science Department at DigitalCommons@University of Nebraska - Lincoln. It has been accepted for inclusion in Faculty Papers and Publications in Animal Science by an authorized administrator of DigitalCommons@University of Nebraska - Lincoln. 


\title{
Genetic response to selection for weaning weight or yearling weight or yearling weight and muscle score in Hereford cattle: Efficiency of gain, growth, and carcass characteristics ${ }^{1,2,3}$
}

\author{
R. M. Koch*, L. V. Cundiff $\dagger$, K. E. Gregory $\dagger$, and L. D. Van Vleck ${ }^{4}$ \\ *Animal Science Department, University of Nebraska, Lincoln 68583-0908 and Roman L. Hruska U. S. Meat \\ Animal Research Center, ARS, USDA, †Clay Center, NE 68933 and $\ddagger$ Lincoln, NE 68583-0908
}

\begin{abstract}
An experiment involving crosses among selection and control lines was conducted to partition direct and maternal additive genetic response to $20 \mathrm{yr}$ of selection for 1) weaning weight, 2) yearling weight, and 3) index of yearling weight and muscle score. Selection response was evaluated for efficiency of gain, growth from birth through market weight, and carcass characteristics. Heritability and genetic correlations among traits were estimated using animal model analyses. Over a time-constant interval, selected lines were heavier, gained more weight, consumed more ME, and had more gain/ME than the control. Over a weightconstant interval, selected lines required fewer days, consumed less ME, had more efficient gains, and required less energy for maintenance than control. Direct and maternal responses were estimated from reciprocal crosses among unselected sires and dams of control and selection lines. Most of the genetic response to selection in all three lines was associated with direct genetic effects, and the highest proportion was from postwean-
\end{abstract}

ing gain. Indirect responses of carcass characteristics to selection over the $20 \mathrm{yr}$ were increased weight of carcasses that had more lean meat, produced with less feed per unit of gain. At a constant carcass weight, selected lines had 1.32 to $1.85 \%$ more retail product and 1.62 to $2.24 \%$ less fat trim and 10/100 to 25/100 degrees less marbling than control. At a constant age, heritability of direct and maternal effects and correlations between them were as follows: market weight, $0.36,0.14$, and 0.10 ; carcass weight, $0.26,0.15$, and 0.03 ; longissimus muscle area, $0.33,0.00$, and 0.00 ; marbling, $0.36,0.07$, and -0.35 ; fat thickness, $0.41,0.05$, and -0.18 ; percentage of kidney, pelvic, and heart fat, 0.12 , 0.08 , and -0.76 ; percentage of retail product, $0.46,0.05$, and -0.29 ; retail product weight, $0.44,0.08,-0.14$; and muscle score, $0.37,0.14$, and -0.54 . Selection criteria in all lines improved efficiency of postweaning gain and increased the amount of salable lean meat on an age- or weight-constant basis, but carcasses had slightly lower marbling scores.

Key Words: Beef Cattle, Carcass, Correlation, Genetic, Heritability, Selection

(c)2004 American Society of Animal Science. All rights reserved.

J. Anim. Sci. 2004. 82:668-682

\section{Introduction}

A selection experiment was initiated in a Hereford population at the Fort Robinson Beef Cattle Research Station, at Crawford, NE, in 1960. Foundation cows,

\footnotetext{
${ }^{1}$ Published as paper No. 14105, Journal Ser., Nebraska Agric. Res. Div., Univ. of Nebraska, Lincoln 68583-0908.

${ }^{2}$ Mention of trade names or companies does not constitute an implied warranty or endorsement by the USDA, the University of Nebraska, or the authors.

${ }^{3}$ Appreciation is expressed to G. E. Dickerson (deceased) for counsel in design and to W. G. Hays, R. Sampson, D. E. Light, P. Beska, and their staff members for operations support in the conduct of this experiment.

${ }^{4}$ Correspondence: A218 Animal Sciences (phone: 402-472-6010; fax: 402-472-6362; e-mail: dvan-vleck1@unl.edu).

Received May 14, 2003.

Accepted November 6, 2003.
}

stratified by pedigree and age, were randomly divided into three lines and selected for 1) weaning weight (WWL), 2) yearling weight (YWL), and 3) an index of yearling weight and muscle score (IXL). A control line (CTL) was established from 1968 to 1971 through AI matings of seven foundation sires and 225 foundation cows or their daughters. A series of analyses were published; for cattle born through 1970 by Koch et al. (1974a,b), for cattle born through 1977 by Buchanan et al. (1982a,b), and for carcass cutout data from heifers born 1963 to 1970 by Koch (1978). Selection was discontinued with calves born in 1982. Descriptive statistics, cumulative selection differentials for sires and dams over the $20 \mathrm{yr}$ (4.65 generations), and estimates of genetic change in weights at birth, weaning and yearling age, muscle score, and the index of yearling weight and muscle score due to selection were published by Koch et al. (1994). A mating design was developed for the 
final phase to partition selection response for direct and maternal additive genetic effects. Selection responses for birth weight, gain to weaning, weaning weight, postweaning gain, yearling weight, and muscle score of these matings were reported by Koch et al. (1995). Selection responses for efficiency of gain, growth and carcass characteristics of selected and control lines, their heritabilities, and correlations are reported here.

\section{Materials and Methods}

Final Phase Design and Populations. Matings for the final phase (calves born from 1983 through 1985) involved crosses among selection and control lines to enable partitioning total genetic differences between selected and control lines into direct genetic, maternal genetic, and heterosis responses. Reciprocal crosses of representative sires and dams of control and selected lines were required to partition genetic responses. Each year, a new sample of six sires from each selection line and 10 sires from CTL were bred in single-sire pastures to random females from control and selected lines. Line codes and expectations of genetic response for line-bred and reciprocal line crosses with CTL are shown in Table 1. Reciprocal crosses among the selection lines were not incorporated into the design because that would have decreased numbers of matings available for reciprocal crosses with CTL, which were essential to partition direct and maternal genetic effects. The design can be considered a connected series of diallel crosses of CTL with WWL, YWL, and IXL.

The following procedures were used to obtain representative sires for the matings and to facilitate the evaluation of correlated responses for carcass characteristics during the final years of the experiment. At weaning from 1979 through 1982, 10 males from each line were selected such that their weaning weights were within a range of -1.5 and $1.5 \mathrm{SD}$ from their contemporary means and such that the sum of their selection differentials was approximately zero. These males were fed a growing diet following normal postweaning protocols for intact males (Koch et al., 1994). Each year, sets of sires with an average performance close to the current average for their line were taken from this pool of sires. Although the numbers of sires selected at weaning were limited, average genetic values of the 18 sires used over the 3-yr period (1980 through 1982) for each line would be expected to be representative of their line for growth and other characteristics. Male calves that were not selected for use in the final phase were castrated after weaning and fed in replicated pens to provide information on gain efficiency and then marketed to provide information on carcass merit in addition to that from animals produced in the final phase.

Management and Feeding. Animals were managed as one herd except during the breeding season. Calves were born in the spring and weighed within $12 \mathrm{~h}$. Calves born from 1980 through 1982 were weaned at an average age of $190 \mathrm{~d}$. Calves born from 1983 through 1985 
were weaned at an average age of $172 \mathrm{~d}$. Males not designated for use as sires in the final phase were castrated after weaning and were divided into replicate pens by line from 1980 through 1982, or into line-typesex pens from 1983 through 1985. Line-type pens were composed of linebred and line crosses. During the postweaning period, animals were fed a diet of $2.69 \mathrm{Mcal}$ of ME/kg of DM and $12.88 \% \mathrm{CP}$ composed of (DM basis) $66 \%$ corn silage, $22 \%$ corn, and $12 \%$ protein-mineral supplement until all pens averaged about 320 to 340 $\mathrm{kg}$. As diets were changed, steers were implanted with Ralgro and heifers were implanted with Synovex-H. Animals were implanted again 90 d later. Subsequently, animals born in 1980 and 1981 were fed a diet of $2.71 \mathrm{Mcal}$ of $\mathrm{ME} / \mathrm{kg} \mathrm{DM}$ and $10.71 \% \mathrm{CP}$ composed of $68.5 \%$ corn silage, $25 \%$ high-moisture corn, and $6.5 \%$ protein-mineral supplement (DM basis) until slaughtered at two end points. Animals born from 1982 through 1985 were fed a diet of $2.93 \mathrm{Mcal}$ of ME/kg DM and $10.83 \% \mathrm{CP}$ composed of (DM basis) $38.5 \%$ corn silage, $56 \%$ corn, and $5.5 \%$ protein-mineral supplement until slaughtered at two end points. A diet of higher energy density was fed after 1981 to achieve larger differences in measures of fatness. The first end point for steers was 430 to $460 \mathrm{~kg}$ and 410 to $420 \mathrm{~kg}$ for heifers. The second end point was approximately 40 to $50 \mathrm{~kg}$ heavier for steers and 30 to $40 \mathrm{~kg}$ heavier for heifers. All animals were fed Rumensin throughout the feeding period. When the average of all animals in linetype-sex pens reached the initial target weight, animals were ranked by weight. A random animal from each ascending weight pair was selected for slaughter to maintain similar gain potential in the first and second slaughter groups. Average days on feed, including adjustment periods after weaning, for 1980 through 1982 was 300 d. For animals born from 1983 through 1985, the average time on feed was $318 \mathrm{~d}$ for steers and 343 $\mathrm{d}$ for heifers.

Analysis of Efficiency of Gain (Pen Mean Analyses). Efficiency of gain (G:F) was evaluated only for animals born from 1980 through 1982. Males not designated for use as sires in the final phase were castrated after weaning and assigned randomly each year to replicate pens (two pens per year for WWL [20 to 28 per pen], YWL [18 to 22 per pen], IXL [23 to 28 per pen], and three pens per year for CTL [27 to 31 per pen]). Not enough pens were available to replicate line-type-sex groups for feed consumption data of animals born from 1983 through 1985. Weight-age curves were computed for each line-year-pen group by linear and quadratic regression of pen means for each 28-d period on days fed. Cumulative ME intake per animal (in megacalories) was also linearly and quadratically regressed on days fed for each pen-year-line group and line group. These regressions were forced through the origin. Pen means of ME intake for steers within a pen for intervals corresponding to weight periods were the observations used in analyses.
Regressions of weight and cumulative megacalories of $\mathrm{ME}$ on days were used for estimating weight, gain, megacalories of ME, and efficiency of live weight gain (kg gain/Mcal ME) for alternate intervals of time. For example, for a weight-common interval from 210 to 452 $\mathrm{kg}$, the initial date $\left(\mathrm{X}_{\mathrm{i}}\right)$, when steers averaged $210 \mathrm{~kg}$, and the final date $\left(\mathrm{X}_{\mathrm{f}}\right)$, when steers averaged $452 \mathrm{~kg}$, was determined from the weight-age curves for each pen of steers. The amount of ME consumed during the corresponding interval was estimated for each pen by subtraction of the cumulative number of megacalories consumed from $\mathrm{d} 0$ to the initial date $\left(\mathrm{X}_{\mathrm{i}}\right)$ from the cumulative number of megacalories of $\mathrm{ME}$ consumed from $\mathrm{d} 0$ to the final date $\left(\mathrm{X}_{\mathrm{f}}\right)$. This procedure was used to estimate the efficiency of live weight gain of steers in each pen for two intervals: time-constant (0 to 295 d) and weight-constant (210 to $452 \mathrm{~kg}$ ). Average time on feed was $300 \mathrm{~d}$.

Daily maintenance energy according to NRC (1970) recommendations was estimated from $0.077 \times$ body weight $^{0.75}$. Cumulative net energy for maintenance $\left(\mathrm{NE}_{\mathrm{m}}\right)$ was predicted for each interval of time by integrating the function $\left(0.077\left[\mathrm{~B}_{0}+\mathrm{B}_{1} \mathrm{X}+\mathrm{B}_{2} \mathrm{X}^{2}\right]^{0.75}\right)$ over the range $X_{i}$ to $X_{f}$, where $X_{i}$ denotes the approximate initial date, $\mathrm{X}_{\mathrm{f}}$ denotes the final date, and $\mathrm{B}_{0}$ is the intercept and $B_{1}$ and $B_{2}$ are linear and quadratic coefficients, respectively, for weight on days on feed X (Cundiff et al., 1981).

Estimates of the efficiency of live weight gain and its components (e.g., megacalories of $\mathrm{ME}$, gain/ME, $\mathrm{NE}_{\mathrm{m}}$ ) for each pen were evaluated by analysis of variance. The residual mean square (pen/line $\times$ year, $6 \mathrm{df}$ ) was used as the error variance of least significant differences among line means.

Analysis of Growth and Carcass Data. Statistical analyses of growth and carcass data were carried out using the mixed model procedure of SAS (SAS Inst., Inc., Cary NC). Data were divided into two sets because of differences in feeding regimen. Set 1 consisted of 587 steers born from 1980 through 1982. Set 2 consisted of 916 animals born from 1983 through 1985 (484 steers and 432 heifers). The mixed model to estimate differences between lines on an age-adjusted basis included fixed effects of year, line, sex, slaughter group, age of dam (where significant), and interactions of year-linesex-slaughter group subclasses, with age at weaning as a covariate and sires within sire lines as random variables. The same model was used to estimate differences between lines at a common carcass weight basis except that hot carcass weight was the covariate.

Growth traits included birth weight (BWT), weaning gain (WGN), weaning weight (WWT), postweaning gain (PWG), market weight (MWT), hot carcass weight (CWT), dressing percentage (DPC), and muscle score (MSC). Carcass traits analyzed were longissimus muscle area (REA); marbling score (MAR); fat thickness at 12 th rib (FTH); estimated percentage of kidney, pelvic, and heart fat (KPH); estimated retail product percentage (RPP); retail product weight (RPW); estimated fat 
trim percentage (FTP); and fat trim weight (FTW). Actual carcass cutout data were not obtained. However, equations (Shackelford et al., 1995) for predicting retail product and fat trim percentages were used to provide estimates of these traits. Retail product was defined as the sum of boneless, totally trimmed (zero fat cover) wholesale cuts (round, loin, rib, chuck, flank, and brisket/plate/foreshank) plus lean trim fabricated to contain $20 \%$ fat. The prediction equations were as follows: $\mathrm{RPP}=74.9-(5.8402 \times \mathrm{FTH}, \mathrm{cm})-(0.0205 \times \mathrm{MAR})+$ $\left(0.1018 \times \mathrm{REA}, \mathrm{cm}^{2}\right)-(1.0384 \times \mathrm{KPH}) ; \mathrm{FTP}=5.1+$ $(7.5795 \times \mathrm{FTH}, \mathrm{cm})+(0.023 \times \mathrm{MAR})+(1.3632 \times \mathrm{KPH}$, $\%)-\left(0.0825 \times \mathrm{REA}, \mathrm{cm}^{2}\right)$. Weights of retail product and fat trim were estimated by multiplying hot carcass weight by their predicted percentages.

\section{Estimates of Genetic and Environmental (Co)Variances}

Estimates of direct and maternal genetic, common environment of dams, random environment, and phenotypic (co)variance components from analyses of bivariate animal model were calculated by derivative-free REML (Smith and Graser, 1986; Graser et al., 1987) with programs of Boldman et al. (1995).

(Co)variances due to direct, maternal, common environment of dams, and random environmental effects and their correlations were obtained from bivariate analyses of birth weight, weaning gain and weight, postweaning gain, yearling weight, and muscle score of animals born in the selection and control lines from 1960 through 1982. The numbers of records for each trait were birth and weaning weight, 9,547; postweaning gain and yearling weight, 8,605; and muscle score, 7,574 . The number of sires was 241 (WWL $=59, \mathrm{YWL}=$ $66, \mathrm{IXL}=61$, and CTL $=55)$. The number of dams was 2,622 (WWL $=722$, YWL $=726$, IXL $=711$, and $\mathrm{CTL}=463)$.

Similarly, bivariate analyses of carcass data were performed using the pooled records of all 1,503 animals born from 1980 through 1985. Records were standardized by dividing each record by phenotypic standard deviations obtained from the mixed model analyses of Data Sets 1 and 2. The number of sires in the pooled data was $136(\mathrm{WWL}=29, \mathrm{YWL}=30, \mathrm{IXL}=30, \mathrm{CTL}=$ 47). The number of dams was $837(\mathrm{WWL}=189, \mathrm{YWL}=$ 181 , IXL $=183$, CTL $=284$ ).

Standard errors of estimates were calculated with the "delta" method (e.g., Dodenhoff, et al., 1998) from the average information matrix calculated at convergence for estimates of the (co)variance components.

\section{Results and Discussion}

\section{Efficiency of Gain (Pen Mean Analyses)}

Least squares means for efficiency of gain (gain/ME, $\mathrm{g} / \mathrm{Mcal}$, components of efficiency, and selection responses deviated from the control line on time-constant and weight-constant intervals are presented in Table 2.
Time-Constant Interval (295 d). Selected lines (WWL, YWL, IXL) were significantly heavier, gained more weight, consumed more $\mathrm{ME}$, and had more gain/ME than the control line for a time-constant interval with ranking of lines: IXL $>$ YWL $>$ WWL $>$ CTL. The differences from CTL were significant only for IXL. The $\mathrm{NE}_{\mathrm{m}}$ for all selected lines was greater than for control line $(P$ $<0.01$ ) because of heavier weights in the selected lines.

Weight-Constant Interval (210 to $452 \mathrm{~kg}$ ). Selected lines (WWL, YWL, IXL) required fewer days to attain $452 \mathrm{~kg}$, consumed significantly fewer megacalories of $\mathrm{ME}$, had more efficient gains, and required less net energy for maintenance than CTL. The more rapid gains of selected line animals meant they needed fewer days to maintain their weight, which may account for most of the differences of gross efficiency. Although the relationship to $\mathrm{NE}_{\mathrm{m}}$ assumes that variation in maintenance requirements is directly proportional to live weight and time on feed, maintenance requirements may also be related to factors such as body composition (Klosterman et al., 1968). The ranking of the lines is similar to the rank of lines when the gain efficiency of bulls from these lines was compared for years 1972 through 1978 (Koch et al., 1982).

\section{Genetic Responses for Growth and Carcass Characteristics in Final Phase}

Genetic responses were estimated as deviations from the control line from linear functions of least squares means. The model for genetic effects was $\mathrm{L}_{\mathrm{ij}}=\mu+0.5\left(\mathrm{a}_{\mathrm{i}}\right.$ $\left.+\mathrm{a}_{\mathrm{j}}\right)+\mathrm{m}_{\mathrm{j}}+\mathrm{h}_{\mathrm{ij}}$, where $\mathrm{i}$ and $\mathrm{j}=1$ (WWL), 2 (YWL), 3 (IXL), or 4 (CTL). The $\mathrm{a}_{\mathrm{i}}$ and $\mathrm{a}_{\mathrm{j}}$ are additive direct contributions from $i^{\text {th }}$ sire line and $j^{\text {th }}$ dam line; $\mathrm{m}_{\mathrm{j}}$ are maternal effects of the $j^{\text {th }}$ dam line; and $h_{i j}$ are heterosis or specific interaction effects associated with crosses of $\mathrm{i}^{\text {th }}$ and $\mathrm{j}^{\text {th }}$ lines. For example, estimates of responses of YWL - CTL were as follows: total $(\mathrm{a}+\mathrm{m})=\mathrm{L}_{22}-\mathrm{L}_{44}$; maternal $(\mathrm{m})=\mathrm{L}_{42}-\mathrm{L}_{24}$; direct $(\mathrm{a})=$ total - maternal = $\mathrm{L}_{22}-\mathrm{L}_{44}-\mathrm{L}_{42}+\mathrm{L}_{24}$; specific heterosis $=0.5\left(\mathrm{~L}_{24}+\mathrm{L}_{42}\right.$ $-\mathrm{L}_{22}-\mathrm{L}_{44}$ ). Any differences in direct or maternal effects of line crosses from that of linebreds are included in specific heterosis effects. Heterosis was expected to be small because heterosis tends to be a recovery of inbreeding depression within lines. Average inbreeding of selected lines at the final phase was only $5.7 \%$. Heterosis effects from crosses among selected and control lines were not significant. Therefore, only average heterosis effects of line crosses were reported.

Gains and weights for each age interval, from birth to slaughter, were evaluated on all animals with carcass records to help interpret direct additive and maternal changes by growth phase and the impact on traits in each line. Results for growth traits are presented in Table 3, for carcass traits in Table 4, and for retail product and fat trim in Table 5.

Birth to Weaning. Total genetic response $(a+m)$ for birth weight was greater than CTL for all selected 
Table 2. Least squares means and genetic response for efficiency of gain (gain/ME, g/ Mcal), and components of efficiency and total responses deviated from control line for time-constant and weight-constant intervals ${ }^{\mathrm{a}, \mathrm{b}}$

\begin{tabular}{|c|c|c|c|c|c|c|}
\hline Item & $\begin{array}{c}\text { Final } \\
\text { wt, kg }\end{array}$ & $\begin{array}{l}\text { Weight } \\
\text { gain, kg }\end{array}$ & $\begin{array}{l}\text { Days } \\
\text { fed }\end{array}$ & $\begin{array}{l}\text { ME, } \\
\text { Mcal }\end{array}$ & $\begin{array}{c}\text { Gain/ME, } \\
\text { g/Mcal }\end{array}$ & $\begin{array}{l}\mathrm{NE}_{\mathrm{m}} \\
\text { Mcal }\end{array}$ \\
\hline & & -1 & -constant & rval ( 0 to & d) & \\
\hline \multicolumn{7}{|c|}{ Least squares means } \\
\hline $\mathrm{L}_{11}=\mathrm{WWL}$ & 515.4 & 305.9 & 295 & 14,196 & 21.59 & 1,876 \\
\hline $\mathrm{L}_{22}=\mathrm{YWL}$ & 517.8 & 312.3 & 295 & 14,263 & 21.92 & 1,876 \\
\hline $\mathrm{L}_{33}=\mathrm{IXL}$ & 543.9 & 326.3 & 295 & 14,611 & 22.49 & 1,938 \\
\hline $\mathrm{L}_{44}=\mathrm{CTL}$ & 466.3 & 276.1 & 295 & 13,140 & 21.06 & 1,748 \\
\hline \multicolumn{7}{|l|}{ Contrasts } \\
\hline $\mathrm{L}_{11}-\mathrm{L}_{44}=\mathrm{a}+\mathrm{m}$ & $49.1^{* *}$ & $29.8^{* *}$ & - & 1,056 & 0.54 & $128^{* * *}$ \\
\hline $\mathrm{L}_{22}-\mathrm{L}_{44}=\mathrm{a}+\mathrm{m}$ & $51.5^{* *}$ & $36.2^{* *}$ & - & 1,122 & 0.86 & $129^{* *}$ \\
\hline $\mathrm{L}_{33}-\mathrm{L}_{44}=\mathrm{a}+\mathrm{m}$ & $77.6^{* *}$ & $50.2^{* *}$ & - & 1,471 & $1.43^{*}$ & $190^{* * *}$ \\
\hline \multirow[t]{2}{*}{$\mathrm{SE}^{\mathrm{b}}$} & 9.6 & 5.1 & - & 530 & 0.53 & 17 \\
\hline & \multicolumn{6}{|c|}{ - Weight-constant interval (210 to $452 \mathrm{~kg}$ ) - } \\
\hline \multicolumn{7}{|c|}{ Least squares means } \\
\hline $\mathrm{L}_{11}=\mathrm{WWL}$ & 452 & 242 & 234.2 & 10,711 & 22.82 & 1,394 \\
\hline $\mathrm{L}_{22}=\mathrm{YWL}$ & 452 & 242 & 229.2 & 10,402 & 23.36 & 1,366 \\
\hline $\mathrm{L}_{33}=\mathrm{IXL}$ & 452 & 242 & 222.7 & 10,148 & 24.18 & 1,321 \\
\hline $\mathrm{L}_{44}=\mathrm{CTL}$ & 452 & 242 & 258.9 & 11,560 & 21.04 & 1,544 \\
\hline \multicolumn{7}{|l|}{ Contrasts } \\
\hline $\mathrm{L}_{11}-\mathrm{L}_{44}=\mathrm{a}+\mathrm{m}$ & - & - & $-24.7 * *$ & $-849 * *$ & 1.78 & $-151^{* * *}$ \\
\hline $\mathrm{L}_{22}-\mathrm{L}_{44}=\mathrm{a}+\mathrm{m}$ & - & - & $-29.7 * *$ & $-1,158^{* *}$ & $2.36^{*}$ & $-178^{\text {*** }}$ \\
\hline $\mathrm{L}_{33}-\mathrm{L}_{44}=\mathrm{a}+\mathrm{m}$ & - & - & $-36.2 * *$ & $-1,410^{* *}$ & $3.14^{* *}$ & $-224^{* * *}$ \\
\hline $\mathrm{SE}^{\mathrm{b}}$ & - & - & 3.2 & 220 & 0.68 & 19 \\
\hline
\end{tabular}

${ }^{\mathrm{a}} \mathrm{WWL}=$ weaning line, $\mathrm{YWL}=$ yearling line, $\mathrm{IXL}=$ index line, $\mathrm{CTL}=$ control line.

${ }^{\mathrm{b}} \mathrm{Standard}$ error of difference from control line.

$* P<0.05$.

$* * P<0.01$

lines $(P>0.01)$, with IXL significantly heavier than WWL and YWL in Set 1 but not in Set 2. Most of the response was due to additive direct genetic effects. Weaning weight represents the end point of direct contact between dam and calf. Although physical expression of maternal environment is removed at weaning, carryover effects can influence postweaning response. Total responses $(\mathrm{a}+\mathrm{m})$ and responses for additive direct (a) effects for weaning weight were significantly greater for all selected lines than CTL. Heaviest was IXL followed by WWL, and YWL. Direct responses (a) were ranked for WWL $>$ YWL $>$ IXL, but differences were not significant. Maternal response (m) for IXL was significantly more and for YWL was less than CTL. Differences between WWL, YWL, and IXL were primarily due to greater maternal ability of IXL and lesser maternal ability of YWL. Means of estimated direct and maternal breeding values (EBV) reported by Koch et al. (1994, table 12 therein) for years 1980 through 1982 for weaning weight of WWL, YWL, and IXL were, respectively, 11, 9.9, and $11 \mathrm{~kg}$ for direct and 2.8, 0.9, and $6 \mathrm{~kg}$ for maternal genetic effects.

Postweaning Gain, Market Weight, Carcass Weight, and Muscle Score. Postweaning gains, market weights, and carcass weights of selected lines were significantly greater than for CTL. Genetic responses were due pri- marily to additive direct effects and were greatest for IXL. Additive direct responses for WWL and YWL were similar. Maternal responses of YWL and IXL for weaning weight were negatively related to their maternal responses for postweaning gain, market, and carcass weights. The extremes of maternal responses for IXL and YWL for weaning gain were almost totally compensated by responses during postweaning growth period. Dressing percentage did not differ significantly among lines.

Muscle score was a criterion of selection in IXL and may be associated with carcass characteristics because the basis for muscle score was estimation of thickness of body discounted for overall fatness (Koch et al., 1994). Response for muscle score of IXL, selected for yearling weight and muscle score, was significantly greater than responses for WWL, YWL, and CTL. Differences in muscle score among lines were primarily due to direct genetic effects.

New Zealand and Australian selection experiments (Baker et al., 1991; Morris et al., 1992; Parnell et al., 1997; Arthur et al., 1997), where lines selected for yearling weight were grown under pasture conditions, provide interesting comparisons with our results where postweaning growth was measured on relatively high-energy diets. The New Zealand selection experiment maintained a progeny test herd and used 
Table 3. Least squares means, genetic response for total $(a+m)$, additive direct $(a)$, maternal $(\mathrm{m})$, and average heterosis of growth traits ${ }^{\mathrm{a}, \mathrm{b}}$

\begin{tabular}{|c|c|c|c|c|c|c|c|c|}
\hline Item & $\begin{array}{c}\text { BWT, } \\
\text { kg }\end{array}$ & $\begin{array}{c}\text { WGN, } \\
\text { kg }\end{array}$ & $\begin{array}{c}\text { WWT, } \\
\text { kg }\end{array}$ & $\begin{array}{c}\text { PWG, } \\
\text { kg }\end{array}$ & $\begin{array}{c}\text { MWT, } \\
\text { kg }\end{array}$ & $\begin{array}{c}\text { CWT, } \\
\mathrm{kg}\end{array}$ & $\begin{array}{c}\mathrm{DPC} \\
\mathrm{kg}\end{array}$ & MSC \\
\hline & & & & et $1(19$ & to 1982 ) & & & \\
\hline \multicolumn{9}{|l|}{ Least squares means } \\
\hline $\mathrm{L}_{11}=\mathrm{WWL}$ & 37.5 & 148.0 & 185.5 & 277.9 & 461.6 & 285.2 & 61.76 & 80.77 \\
\hline $\mathrm{L}_{22}=\mathrm{YWL}$ & 37.5 & 141.2 & 178.8 & 288.0 & 466.8 & 289.4 & 61.93 & 79.79 \\
\hline $\mathrm{L}_{33}=\mathrm{IXL}$ & 39.5 & 150.5 & 190.0 & 296.5 & 486.6 & 299.1 & 61.42 & 81.62 \\
\hline $\mathrm{L}_{44}=\mathrm{CTL}$ & 33.9 & 135.5 & 169.2 & 253.1 & 422.7 & 260.9 & 61.67 & 79.62 \\
\hline \multicolumn{9}{|l|}{ Contrasts } \\
\hline $\mathrm{L}_{11}-\mathrm{L}_{44}=\mathrm{a}+\mathrm{m}$ & 3.6 & 12.5 & 16.3 & 24.8 & 38.9 & 24.3 & 0.09 & 1.15 \\
\hline $\mathrm{L}_{22}-\mathrm{L}_{44}=\mathrm{a}+\mathrm{m}$ & 3.5 & 5.7 & 9.6 & 34.9 & 44.1 & 28.5 & 0.25 & 0.18 \\
\hline \multirow[t]{2}{*}{$\mathrm{L}_{33}-\mathrm{L}_{44}=\mathrm{a}+\mathrm{m}$} & 5.6 & 15.0 & 20.8 & 43.4 & 63.9 & 38.1 & -0.25 & 2.00 \\
\hline & & & & \multicolumn{2}{|c|}{ Set 2 (1983 to 1985$)$} & & & \\
\hline \multicolumn{9}{|l|}{ Least squares means } \\
\hline $\mathrm{L}_{11}=\mathrm{WWL}$ & 34.7 & 123.4 & 158.3 & 306.1 & 464.4 & 292.3 & 62.96 & 81.49 \\
\hline $\mathrm{L}_{22}=\mathrm{YWL}$ & 35.2 & 117.4 & 152.5 & 316.0 & 468.5 & 292.8 & 62.47 & 81.37 \\
\hline $\mathrm{L}_{33}=\mathrm{IXL}$ & 35.7 & 124.1 & 159.6 & 320.3 & 480.2 & 300.1 & 62.49 & 82.10 \\
\hline $\mathrm{L}_{44}=\mathrm{CTL}$ & 31.5 & 113.1 & 144.7 & 287.7 & 432.5 & 270.5 & 62.55 & 80.81 \\
\hline $\mathrm{L}_{14}=\mathrm{WWL} \times \mathrm{CTL}$ & 33.8 & 118.7 & 152.4 & 298.9 & 451.3 & 281.6 & 62.37 & 81.37 \\
\hline $\mathrm{L}_{41}=\mathrm{CTL} \times \mathrm{WWL}$ & 33.5 & 120.1 & 153.6 & 299.6 & 453.2 & 283.8 & 62.63 & 81.25 \\
\hline $\mathrm{L}_{21}=\mathrm{YWL} \times \mathrm{CTL}$ & 33.1 & 117.9 & 151.0 & 295.8 & 446.8 & 279.1 & 62.48 & 80.68 \\
\hline $\mathrm{L}_{12}=\mathrm{CTL} \times \mathrm{YWL}$ & 32.4 & 115.3 & 147.8 & 304.0 & 451.6 & 282.0 & 62.46 & 80.76 \\
\hline $\mathrm{L}_{34}=\mathrm{IXL} \times \mathrm{CTL}$ & 33.3 & 118.4 & 151.6 & 309.1 & 460.8 & 289.9 & 62.92 & 81.25 \\
\hline $\mathrm{L}_{43}=\mathrm{CTL} \times \mathrm{IXL}$ & 33.8 & 124.9 & 158.6 & 301.1 & 459.9 & 287.8 & 62.56 & 81.23 \\
\hline \multicolumn{9}{|l|}{ Contrasts } \\
\hline $\mathrm{L}_{11}-\mathrm{L}_{44}=\mathrm{a}+\mathrm{m}$ & 3.2 & 10.3 & 13.6 & 18.3 & 31.9 & 21.8 & 0.41 & 0.68 \\
\hline $\mathrm{L}_{22}-\mathrm{L}_{44}=\mathrm{a}+\mathrm{m}$ & 3.7 & 4.4 & 7.8 & 28.3 & 36.0 & 22.3 & -0.08 & 0.56 \\
\hline $\mathrm{L}_{33}-\mathrm{L}_{44}=\mathrm{a}+\mathrm{m}$ & 4.2 & 11.1 & 14.8 & 32.5 & 47.7 & 29.6 & -0.06 & 1.29 \\
\hline $\mathrm{SE}^{\mathrm{b}}$ & 0.7 & 2.6 & 2.8 & 4.8 & 6.3 & 6.4 & 0.26 & 0.22 \\
\hline $\mathrm{L}_{11}-\mathrm{L}_{44}-\mathrm{L}_{41}+\mathrm{L}_{14}=\mathrm{a}$ & 3.5 & 9.0 & 12.3 & 17.6 & 30.0 & 19.6 & 0.15 & 0.80 \\
\hline $\mathrm{L}_{22}-\mathrm{L}_{44}-\mathrm{L}_{42}+\mathrm{L}_{24}=\mathrm{a}$ & 4.4 & 7.0 & 11.0 & 20.2 & 31.1 & 19.4 & -0.06 & 0.48 \\
\hline $\mathrm{L}_{33}-\mathrm{L}_{44}-\mathrm{L}_{43}+\mathrm{L}_{34}=\mathrm{a}$ & 3.6 & 4.6 & 7.9 & 40.5 & 48.6 & 31.7 & 0.30 & 1.31 \\
\hline $\mathrm{SE}^{\mathrm{b}}$ & 1.1 & 3.6 & 3.9 & 7.7 & 10.0 & 6.3 & 0.41 & 0.35 \\
\hline $\mathrm{L}_{41}-\mathrm{L}_{14}=\mathrm{m}$ & -0.3 & 1.4 & 1.2 & 0.7 & 1.9 & 2.2 & 0.26 & -0.12 \\
\hline $\mathrm{L}_{42}-\mathrm{L}_{24}=\mathrm{m}$ & -0.6 & -2.6 & -3.2 & 8.2 & 4.9 & 2.9 & -0.02 & 0.08 \\
\hline $\mathrm{L}_{43}-\mathrm{L}_{34}=\mathrm{m}$ & 0.6 & 6.4 & 7.0 & -8.0 & -0.9 & -2.1 & -0.35 & -0.02 \\
\hline $\mathrm{SE}^{\mathrm{b}}$ & 0.7 & 2.6 & 2.7 & 4.6 & 6.1 & 4.0 & 0.25 & 0.22 \\
\hline Avg heterosis & 0.0 & 1.9 & 1.8 & 0.5 & 2.2 & 1.3 & -0.03 & -0.14 \\
\hline $\mathrm{SE}^{\mathrm{b}}$ & 0.3 & 1.3 & 1.4 & 1.9 & 2.6 & 1.8 & 0.11 & 0.10 \\
\hline
\end{tabular}

${ }^{\mathrm{a}} \mathrm{BWT}=$ birth weight, $\mathrm{WGN}=$ weaning gain, $\mathrm{WWT}=$ weaning weight, $\mathrm{PWG}=$ postweaning gain, $\mathrm{MWT}=$ market weight, $\mathrm{CWT}=$ hot carcass weight, $\mathrm{DPC}=$ dressing percentage, $\mathrm{MSC}=$ muscle score, $\mathrm{WWL}=$ weaning line, $\mathrm{YWL}=$ yearling line, IXL = index line, $\mathrm{CTL}=$ control line.

${ }^{\mathrm{b}}$ Standard error of difference from control line.

a cross-classification of sire source and source of sire of dam to estimate direct and maternal effects of the Angus lines free from confounding inherent in closed selection herds. Means of control progeny and the direct and maternal effects of selection line progeny, expressed as deviations from control, were birth weight, 27.0, 0.8, and $2.4 \mathrm{~kg}$; weaning gain, 128.5, 5.9, and $2.6 \mathrm{~kg}$; postweaning gain, $72.5,6.0$, and $-7.1 \mathrm{~kg}$; yearling weight, 229.8, 11.6, and $-0.3 \mathrm{~kg}$ (Morris et al., 1992). Means for the control line and the responses for high-gain line as deviations from control for the Australian experiment were birth weight, 31 and 3 $\mathrm{kg}$; weaning weight, 197 and $26 \mathrm{~kg}$; and yearling weight, 312 and $38 \mathrm{~kg}$, respectively. Herd (1990) indicated that $18 \%$ and $11 \%$ of the correlated responses, which would be approximately $4.7 \mathrm{~kg}$ for weaning and
$4.2 \mathrm{~kg}$ for yearling weights, respectively, were due to maternal effects. In the New Zealand data, the compensation for preweaning maternal effects in postweaning gains was essentially gone by yearling age. The maternal response for yearling weight in the Australian line was negligible. Differences in responses for the three experiments could be due to many factors, such as breeds, environments, management, selection intensity, numbers of generations, and method of analysis as well as chance.

Carcass Characteristics at Constant Age and Constant Carcass Weight. Longissimus muscle areas of WWL, YWL, and IXL were significantly larger than CTL at a constant age. Longissimus muscle area for IXL was significantly larger than for WWL and YWL in Set 1. In Set 2, longissimus muscle areas for WWL 
Table 4. Least squares means, and genetic response, total $(a+m)$, additive direct $(a)$, maternal (m), and average heterosis for growth traits at a constant-age (AGE) and at a constant carcass weight $(\mathrm{CWT})^{\mathrm{a}, \mathrm{b}}$

\begin{tabular}{|c|c|c|c|c|c|c|c|c|}
\hline \multirow[b]{2}{*}{ Item } & \multicolumn{2}{|c|}{$\mathrm{REA}, \mathrm{cm}^{2}$} & \multicolumn{2}{|c|}{ MAR } & \multicolumn{2}{|c|}{ FTH, mm } & \multicolumn{2}{|c|}{$\mathrm{KPH}, \%$} \\
\hline & AGE & CWT & AGE & CWT & AGE & CWT & AGE & CWT \\
\hline & & & & Set $1(1 S$ & to 198 & & & \\
\hline \multicolumn{9}{|l|}{ Least squares means } \\
\hline $\mathrm{L}_{11}=\mathrm{WWL}$ & 71.6 & 71.1 & 584 & 583 & 9.0 & 8.6 & 2.97 & 2.95 \\
\hline $\mathrm{L}_{22}=\mathrm{YWL}$ & 71.4 & 70.6 & 582 & 579 & 10.1 & 9.5 & 3.00 & 2.97 \\
\hline $\mathrm{L}_{33}=\mathrm{IXL}$ & 73.9 & 71.8 & 603 & 594 & 9.0 & 7.8 & 2.97 & 2.87 \\
\hline $\mathrm{L}_{44}=\mathrm{CTL}$ & 69.7 & 71.8 & 594 & 604 & 9.5 & 10.6 & 2.94 & 3.05 \\
\hline \multicolumn{9}{|l|}{ Contrasts } \\
\hline $\mathrm{L}_{11}-\mathrm{L}_{44}=\mathrm{a}+\mathrm{m}$ & 1.9 & -0.7 & -10 & -21 & -0.6 & -1.9 & 0.03 & -0.11 \\
\hline $\mathrm{L}_{22}-\mathrm{L}_{44}=\mathrm{a}+\mathrm{m}$ & 1.7 & -1.2 & -12 & -25 & 0.5 & -1.1 & 0.06 & -0.09 \\
\hline $\mathrm{L}_{33}-\mathrm{L}_{44}=\mathrm{a}+\mathrm{m}$ & 4.2 & 0.0 & 9 & -10 & -0.5 & -2.7 & 0.02 & -0.19 \\
\hline \multirow[t]{2}{*}{$\begin{array}{l}\mathrm{L}_{33}-\mathrm{L}_{44}=\mathrm{a}+\mathrm{II} \\
\end{array}$} & 0.7 & 0.7 & 10 & 10 & 0.5 & 0.5 & 0.05 & 0.06 \\
\hline & & & & \multicolumn{2}{|c|}{ Set $2(1983$ to 1985$)$} & & & \\
\hline \multicolumn{9}{|l|}{ Least squares means } \\
\hline $\mathrm{L}_{11}=\mathrm{WWL}$ & 72.1 & 71.5 & 652 & 651 & 13.0 & 12.6 & 2.97 & 2.93 \\
\hline $\mathrm{L}_{22}=\mathrm{YWL}$ & 69.8 & 69.1 & 637 & 634 & 14.3 & 13.7 & 2.92 & 2.88 \\
\hline $\mathrm{L}_{33}=\mathrm{IXL}$ & 71.7 & 70.1 & 669 & 660 & 13.6 & 12.6 & 2.99 & 2.90 \\
\hline $\mathrm{L}_{44}=\mathrm{CTL}$ & 68.5 & 70.2 & 664 & 677 & 13.7 & 14.6 & 2.87 & 2.96 \\
\hline $\mathrm{L}_{14}=\mathrm{WWL} \times \mathrm{CTL}$ & 68.9 & 69.3 & 665 & 670 & 13.1 & 13.2 & 2.85 & 2.87 \\
\hline $\mathrm{L}_{41}=\mathrm{CTL} \times \mathrm{WWL}$ & 70.1 & 70.4 & 663 & 666 & 14.1 & 14.2 & 3.02 & 3.03 \\
\hline $\mathrm{L}_{21}=\mathrm{YWL} \times \mathrm{CTL}$ & 69.4 & 70.2 & 650 & 657 & 14.3 & 14.7 & 2.90 & 2.94 \\
\hline $\mathrm{L}_{12}=\mathrm{CTL} \times \mathrm{YWL}$ & 69.0 & 69.5 & 664 & 670 & 14.3 & 14.5 & 2.92 & 2.95 \\
\hline $\mathrm{L}_{34}=\mathrm{IXL} \times \mathrm{CTL}$ & 70.4 & 69.9 & 677 & 676 & 13.9 & 13.5 & 2.94 & 2.91 \\
\hline $\mathrm{L}_{43}=\mathrm{CTL} \times \mathrm{IXL}$ & 71.2 & 70.9 & 677 & 677 & 13.3 & 13.0 & 2.91 & 2.89 \\
\hline \multicolumn{9}{|l|}{ Contrasts } \\
\hline $\mathrm{L}_{11}-\mathrm{L}_{44}=\mathrm{a}+\mathrm{m}$ & 3.6 & 1.2 & -11 & -26 & -0.7 & -2.0 & 0.10 & -0.03 \\
\hline $\mathrm{L}_{22}-\mathrm{L}_{44}=\mathrm{a}+\mathrm{m}$ & 1.4 & -1.2 & -26 & -43 & 0.6 & -0.8 & 0.05 & -0.08 \\
\hline $\mathrm{L}_{33}-\mathrm{L}_{44}=\mathrm{a}+\mathrm{m}$ & 3.3 & -0.1 & 5 & -18 & -0.1 & -2.0 & 0.12 & -0.06 \\
\hline $\mathrm{SE}^{\mathrm{b}}$ & 1.1 & 1.0 & 15 & 15 & 0.8 & 0.8 & 0.08 & 0.08 \\
\hline $\mathrm{L}_{11}-\mathrm{L}_{44}-\mathrm{L}_{41}+\mathrm{L}_{14}=\mathrm{a}$ & 2.5 & 0.2 & -9 & -23 & -1.8 & -3.0 & -0.07 & -0.18 \\
\hline $\mathrm{L}_{22}-\mathrm{L}_{44}-\mathrm{L}_{42}+\mathrm{L}_{24}=\mathrm{a}$ & 1.8 & -0.5 & -40 & -56 & 0.7 & -0.7 & 0.03 & -0.09 \\
\hline $\mathrm{L}_{33}-\mathrm{L}_{44}-\mathrm{L}_{43}+\mathrm{L}_{34}=\mathrm{a}$ & 2.5 & -1.2 & 5 & -19 & 0.6 & -1.5 & 0.15 & -0.05 \\
\hline $\mathrm{SE}^{\mathrm{b}}$ & 1.8 & 1.8 & 23 & 24 & 1.3 & 1.3 & 0.11 & 0.11 \\
\hline $\mathrm{L}_{41}-\mathrm{L}_{14}=\mathrm{m}$ & 1.2 & 1.0 & -3 & -4 & 1.1 & 1.0 & 0.17 & 0.16 \\
\hline $\mathrm{L}_{42}-\mathrm{L}_{24}=\mathrm{m}$ & -0.5 & -0.7 & 14 & 12 & 0.0 & -0.2 & 0.02 & 0.01 \\
\hline $\mathrm{L}_{43}-\mathrm{L}_{34}=\mathrm{m}$ & 0.7 & 1.1 & 0 & 2 & -0.6 & -0.5 & -0.03 & -0.02 \\
\hline $\mathrm{SE}^{\mathrm{b}}$ & 1.1 & 1.0 & 15 & 15 & 0.8 & 0.7 & 0.07 & 0.07 \\
\hline Avg heterosis & 0.0 & -0.2 & 8 & 7 & 0.2 & 0.1 & 0.01 & 0.00 \\
\hline $\mathrm{SE}^{\mathrm{b}}$ & 0.5 & 0.4 & 7 & 6 & 0.3 & 0.3 & 0.04 & 0.03 \\
\hline
\end{tabular}

${ }^{a}$ REA = longissimus muscle area; MAR $=$ marbling score $\left(400=\operatorname{slight}^{00}, 500=\operatorname{small}^{00}, 600=\right.$ modest $\left.^{00}\right)$; FTH = adjusted fat thickness; KPH = estimated percentage of kidney, pelvic, and heart fat; WWL = weaning line; YWL = yearling line; IXL = index line; CTL = control line.

${ }^{\mathrm{b}} \mathrm{Standard}$ error of difference from control line.

and IXL were similar but both were larger than for YWL. At a constant carcass weight, the only significant difference in Set 2 was between WWL and YWL.

In Sets 1 and 2, the ranking for marbling score at a constant age was IXL $>$ CTL $>$ WWL $>$ YWL, but the only significant difference was between IXL and YWL. At a constant carcass weight, the only significant differences were for CTL vs. WWL and YWL in Set 1 and for CTL and IXL vs. YWL in Set 2.

At a constant age, the ranking for fat thickness was YWL > CTL > IXL > WWL, with YWL significantly greater than WWL and IXL in Set 1 but not in Set 2 . At a constant carcass weight, the means of WWL, YWL, IXL, and CTL were, respectively, 8.6, 9.4, 7.9, and 10.6 $\mathrm{mm}$ for Set 1 and 12.6, 13.8, 12.6, and $14.5 \mathrm{~mm}$ for Set 2. Fat thickness of CTL was significantly greater for all contrasts with selected lines except for YWL in Set 2.

Kidney, pelvic, and heart fat as a percentage of carcass weight was estimated by the visual appraisal of a trained carcass grader. Differences among lines were not significant at a constant age or carcass weight.

Predicted Retail Product and Fat Trim. Lines did not differ significantly for retail product or fat trim percentages at a constant age (Table 5). At a constant carcass weight, all selected lines had higher retail product and lower fat trim percentages than CTL $(P<0.01)$. Retail product percentage decreased and fat trim percentage increased as carcass weight increased. All selected lines 
Table 5. Least squares means, and genetic response, total $(a+m)$, additive direct $(a)$, maternal (m), and average heterosis for growth traits at a constant-age (AGE) and at a constant carcass weight $(\mathrm{CWT})^{\mathrm{a}, \mathrm{b}}$

\begin{tabular}{|c|c|c|c|c|c|c|c|c|}
\hline \multirow[b]{2}{*}{ Item } & \multicolumn{4}{|c|}{ Retail product } & \multicolumn{4}{|c|}{ Fat trim } \\
\hline & $\begin{array}{c}\mathrm{AGE} \\
\%\end{array}$ & $\begin{array}{c}\text { CWT, } \\
\%\end{array}$ & $\begin{array}{c}\mathrm{AGE}, \\
\mathrm{kg}\end{array}$ & $\begin{array}{c}\text { CWT, } \\
\mathrm{kg}\end{array}$ & $\begin{array}{c}\mathrm{AGE} \\
\%\end{array}$ & $\begin{array}{c}\text { CWT, } \\
\%\end{array}$ & $\begin{array}{c}\mathrm{AGE}, \\
\mathrm{kg}\end{array}$ & $\begin{array}{c}\text { CWT } \\
\text { kg }\end{array}$ \\
\hline & & & & Set $1(1 S$ & to 1982$)$ & & & \\
\hline \multicolumn{9}{|l|}{ Least squares means } \\
\hline $\mathrm{L}_{11}=\mathrm{WWL}$ & 61.94 & 62.10 & 175.8 & 173.5 & 23.41 & 23.18 & 66.9 & 65.1 \\
\hline $\mathrm{L}_{22}=\mathrm{YWL}$ & 61.33 & 61.60 & 175.7 & 172.0 & 24.19 & 23.81 & 69.9 & 67.1 \\
\hline $\mathrm{L}_{33}=\mathrm{IXL}$ & 61.73 & 62.48 & 184.1 & 174.4 & 23.73 & 22.69 & 71.5 & 63.9 \\
\hline $\mathrm{L}_{44}=\mathrm{CTL}$ & 61.26 & 60.49 & 158.6 & 168.9 & 24.16 & 25.23 & 63.2 & 71.1 \\
\hline \multicolumn{9}{|l|}{ Contrasts } \\
\hline $\mathrm{L}_{11}-\mathrm{L}_{44}=\mathrm{a}+\mathrm{m}$ & 0.67 & 1.61 & 17.2 & 4.6 & -0.75 & -2.05 & 3.7 & -6.0 \\
\hline $\mathrm{L}_{22}-\mathrm{L}_{44}=\mathrm{a}+\mathrm{m}$ & 0.07 & 1.11 & 17.1 & 3.1 & 0.03 & -1.42 & 7.4 & -4.0 \\
\hline $\mathrm{L}_{33}-\mathrm{L}_{44}=\mathrm{a}+\mathrm{m}$ & 0.47 & 1.98 & 25.5 & 5.5 & -0.43 & -2.54 & 7.9 & -7.1 \\
\hline $\mathrm{SE}^{\mathrm{b}}$ & 0.41 & 0.43 & 1.9 & 1.2 & 0.50 & 0.52 & 1.8 & 1.5 \\
\hline \multicolumn{9}{|l|}{ Least squares means } \\
\hline $\mathrm{L}_{11}=\mathrm{WWL}$ & 58.23 & 58.43 & 169.8 & 167.4 & 28.02 & 27.72 & 82.5 & 79.6 \\
\hline $\mathrm{L}_{22}=\mathrm{YWL}$ & 57.56 & 57.90 & 168.1 & 165.8 & 28.82 & 28.35 & 84.9 & 81.5 \\
\hline $\mathrm{L}_{33}=\mathrm{IXL}$ & 57.48 & 58.18 & 172.4 & 166.8 & 28.90 & 27.94 & 87.0 & 80.1 \\
\hline $\mathrm{L}_{44}=\mathrm{CTL}$ & 57.33 & 56.58 & 154.6 & 161.9 & 28.96 & 29.96 & 79.0 & 86.2 \\
\hline $\mathrm{L}_{14}=\mathrm{WWL} \times \mathrm{CTL}$ & 57.68 & 57.52 & 161.9 & 164.5 & 28.51 & 28.73 & 81.0 & 82.7 \\
\hline $\mathrm{L}_{41}=\mathrm{CTL} \times \mathrm{WWL}$ & 57.05 & 56.93 & 161.5 & 162.9 & 29.39 & 29.56 & 83.9 & 85.0 \\
\hline $\mathrm{L}_{21}=\mathrm{YWL} \times \mathrm{CTL}$ & 57.26 & 56.94 & 159.5 & 163.0 & 29.14 & 29.56 & 81.8 & 84.9 \\
\hline $\mathrm{L}_{12}=\mathrm{CTL} \times \mathrm{YWL}$ & 56.94 & 56.71 & 160.4 & 162.5 & 29.49 & 29.79 & 83.5 & 85.4 \\
\hline $\mathrm{L}_{34}=\mathrm{IXL} \times \mathrm{CTL}$ & 57.01 & 57.26 & 164.9 & 164.0 & 29.42 & 29.07 & 85.7 & 83.4 \\
\hline $\mathrm{L}_{43}=\mathrm{CTL} \times \mathrm{IXL}$ & 57.50 & 57.65 & 165.0 & 164.9 & 28.82 & 28.61 & 83.7 & 82.4 \\
\hline \multicolumn{9}{|l|}{ Contrasts } \\
\hline $\mathrm{L}_{11}-\mathrm{L}_{44}=\mathrm{a}+\mathrm{m}$ & 0.90 & 1.85 & 15.2 & 5.4 & -0.94 & -2.24 & 3.5 & -6.6 \\
\hline $\mathrm{L}_{22}-\mathrm{L}_{44}=\mathrm{a}+\mathrm{m}$ & 0.23 & 1.32 & 13.4 & 3.8 & -0.13 & -1.62 & 5.9 & -4.7 \\
\hline $\mathrm{L}_{33}-\mathrm{L}_{44}=\mathrm{a}+\mathrm{m}$ & 0.15 & 1.60 & 17.7 & 4.8 & -0.05 & -2.02 & 8.0 & -6.1 \\
\hline $\mathrm{SE}^{\mathrm{b}}$ & 0.64 & 0.65 & 2.7 & 1.9 & 0.78 & 0.78 & 2.8 & 2.3 \\
\hline $\mathrm{L}_{11}-\mathrm{L}_{44}-\mathrm{L}_{41}+\mathrm{L}_{14}=\mathrm{a}$ & 1.52 & 2.43 & 15.6 & 7.0 & -1.82 & -3.07 & 0.5 & -8.9 \\
\hline $\mathrm{L}_{22}-\mathrm{L}_{44}-\mathrm{L}_{42}+\mathrm{L}_{24}=\mathrm{a}$ & 0.55 & 1.56 & 12.5 & 4.4 & -0.48 & -1.85 & 4.2 & -5.2 \\
\hline $\mathrm{L}_{33}-\mathrm{L}_{44}-\mathrm{L}_{43}+\mathrm{L}_{34}=\mathrm{a}$ & -0.34 & 1.21 & 17.7 & 3.9 & 0.54 & -1.56 & 10.1 & -5.1 \\
\hline $\mathrm{SE}^{\mathrm{b}}$ & 1.04 & 1.06 & 4.4 & 3.1 & 1.28 & 1.30 & 4.4 & 3.8 \\
\hline $\mathrm{L}_{41}-\mathrm{L}_{14}=\mathrm{m}$ & -0.63 & -0.59 & -0.4 & -1.6 & 0.88 & 0.83 & 2.9 & 2.3 \\
\hline $\mathrm{L}_{42}-\mathrm{L}_{24}=\mathrm{m}$ & -0.32 & -0.24 & 0.9 & -0.6 & 0.35 & 0.23 & 1.7 & 0.5 \\
\hline $\mathrm{L}_{43}-\mathrm{L}_{34}=\mathrm{m}$ & 0.49 & 0.39 & 0.0 & 0.9 & -0.60 & -0.46 & -2.1 & -1.0 \\
\hline $\mathrm{SE}^{\mathrm{b}}$ & 0.62 & 0.62 & 2.7 & 1.8 & 0.76 & 0.76 & 2.7 & 2.2 \\
\hline Avg heterosis & -0.30 & -0.21 & -0.2 & -0.6 & 0.36 & 0.24 & 1.4 & 0.7 \\
\hline $\mathrm{SE}^{\mathrm{b}}$ & 0.25 & 0.25 & 1.1 & 0.7 & 0.31 & 0.30 & 1.2 & 0.9 \\
\hline
\end{tabular}

${ }^{\mathrm{a}} \mathrm{REA}=$ longissimus muscle area; MAR $=$ marbling score $\left(400=\operatorname{slight}^{00}, 500=\operatorname{small}^{00}, 600=\operatorname{modest}^{00}\right)$; FTH = adjusted fat thickness; KPH = estimated percentage of kidney, pelvic, and heart fat; WWL = weaning line; YWL = yearling line; IXL = index line; $\mathrm{CTL}=$ control line.

${ }^{\mathrm{b}} \mathrm{Standard}$ error of difference from control line.

had significantly heavier carcass weights at a constant age. The YWL had lower retail product and higher fat trim percentages than WWL and IXL. The YWL was associated with greater fat thickness and smaller longissimus muscle area relative to WWL or IXL. The higher percentage of retail product and lower percentage of fat trim in Set 1 compared with Set 2 was associated with fewer days fed and slightly lower energy density of diets of Set 1.

Weights of retail product and fat trim for all selected lines were significantly greater than CTL at a constant age due to heavier carcasses of selected lines. At a constant carcass weight, carcasses of selected lines had 3.1 to $5.6 \mathrm{~kg}$ more retail product and 4.0 to $6.5 \mathrm{~kg}$ less fat trim than CTL $(P<0.03$ to $P<0.0001)$. In the New Zealand and Australian selection experiments, allometric analyses of carcass components of serially slaughtered animals were conducted. Morris et al. (1993) indicated "no significant herd differences in the rate at which salable meat, bone, or trimmed fat weights increased with carcass weight." Perry and Arthur (2000) concluded that "when slaughtered to attain a particular carcass weight, steers selected for high growth rate will be younger, less mature, and will have higher bone weights, lower level of fat, and similar level of muscle than will unselected animals." 
Table 6. Proportions of additive direct (a), maternal (m), common environment of dam (d), random environment (e) effects, and correlations of growth traits ${ }^{\mathrm{a}, \mathrm{b}}$

\begin{tabular}{|c|c|c|c|c|c|c|c|}
\hline Item & BWT & WGN & WWT & PWG & YWT & MSC & ASE \\
\hline & & & \multicolumn{3}{|c|}{ Proportion of phenotypic variance } & & \\
\hline$a^{2}$ & 0.46 & 0.15 & 0.17 & 0.41 & 0.42 & 0.34 & $(0.03)$ \\
\hline $\mathrm{m}^{2}$ & 0.11 & 0.19 & 0.18 & 0.03 & 0.08 & 0.03 & $(0.02)$ \\
\hline $\operatorname{Cov}_{\mathrm{am}}$ & 0.016 & -0.055 & -0.050 & -0.018 & 0.015 & -0.008 & \\
\hline $\mathrm{h}_{\mathrm{t}}^{2}$ & 0.54 & 0.16 & 0.19 & 0.39 & 0.48 & 0.35 & \\
\hline $\mathrm{d}^{2}$ & 0.02 & 0.26 & 0.25 & 0.01 & 0.05 & 0.01 & $(0.02)$ \\
\hline \multirow[t]{2}{*}{$\mathrm{e}^{2}$} & 0.40 & 0.45 & 0.44 & 0.57 & 0.44 & 0.63 & $(0.02)$ \\
\hline & $\begin{array}{c}1 \\
\text { mi.m1 }\end{array}$ & $\begin{array}{c}2 \\
\text { mi.m2 }\end{array}$ & $\begin{array}{c}3 \\
\text { mi.m3 }\end{array}$ & $\begin{array}{c}\text { Correlations } \\
4 \\
\text { mi.m4 }\end{array}$ & $\begin{array}{c}5 \\
\text { mi.m5 }\end{array}$ & $\begin{array}{c}6 \\
\text { mi.m6 }\end{array}$ & mi.mj \\
\hline 1. BWT a1.aj & - & 0.23 & 0.37 & 0.40 & 0.48 & 0.03 & $(0.20)$ \\
\hline 2. WGN a2.aj & 0.27 & - & - & -0.27 & 0.93 & 0.95 & $(0.26)$ \\
\hline 3. WWT a3.aj & 0.53 & - & - & -0.20 & 0.91 & 0.89 & $(0.27)$ \\
\hline 4. PWG a4.aj & 0.53 & 0.47 & 0.56 & - & 0.13 & -0.06 & $(0.26)$ \\
\hline 5. YWT a5.aj & 0.57 & 0.75 & 0.81 & 0.94 & - & 0.87 & $(0.32)$ \\
\hline \multirow{3}{*}{$\begin{array}{l}\text { 6. MSC a6.aj } \\
\begin{aligned} \text { ASE } & \text { ai.aj } \\
& \text { i.j }\end{aligned}\end{array}$} & 0.24 & 0.16 & 0.22 & 0.12 & 0.17 & - & $(0.37)$ \\
\hline & $(0.10)$ & $(0.13)$ & $(0.14)$ & $(0.12)$ & $(0.15)$ & $(0.10)$ & \\
\hline & ai.m1 & ai.m2 & ai.m3 & ai.m4 & ai.m5 & ai.m6 & ai.mj \\
\hline 1. BWT a1.mj & 0.07 & -0.23 & -0.21 & -0.16 & -0.28 & -0.30 & $(0.12)$ \\
\hline 2. WGNa2.mj & 0.31 & -0.32 & - & 0.19 & -0.25 & -0.22 & $(0.16)$ \\
\hline 3. WWTa3.mj & 0.29 & - & -0.28 & 0.12 & -0.26 & -0.27 & $(0.15)$ \\
\hline 4. PWG a4.mj & 0.38 & 0.30 & 0.34 & -0.17 & 0.29 & 0.23 & $(0.13)$ \\
\hline 5. YWT a5.mj & 0.44 & 0.03 & 0.11 & -0.10 & 0.08 & 0.03 & $(0.12)$ \\
\hline \multirow{3}{*}{$\begin{array}{l}\text { 6. MSC a6.mj } \\
\text { ASE ai.mj } \\
\text { i.j. }\end{array}$} & -0.04 & -0.05 & -0.06 & 0.17 & -0.03 & -0.08 & $(0.14)$ \\
\hline & $(0.11)$ & $(0.10)$ & $(0.10)$ & $(0.18)$ & $(0.12)$ & $(0.18)$ & \\
\hline & ei.e1 & ei.e2 & ei.e3 & ei.e4 & ei.e5 & ei.e6 & ei.ej \\
\hline 1. BWT p1.pj & - & 0.13 & 0.30 & 0.10 & 0.25 & 0.01 & $(0.04)$ \\
\hline 2. WGN p2.pj & 0.17 & - & 1.00 & 0.03 & 0.63 & 0.23 & $(0.04)$ \\
\hline 3. WWT p3.pj & 0.34 & 1.00 & - & 0.05 & 0.66 & 0.23 & $(0.04)$ \\
\hline 4. PWG p4.pj & 0.32 & 0.11 & 0.17 & - & 0.80 & 0.37 & $(0.04)$ \\
\hline 5. YWT p5.pj & 0.43 & 0.70 & 0.75 & 0.79 & - & 0.43 & $(0.06)$ \\
\hline 6. MSC p6.pj & 0.08 & 0.26 & 0.27 & 0.28 & 0.35 & - & $(0.03)$ \\
\hline
\end{tabular}

${ }^{a}$ BWT $=$ birth weight; WGN = weaning gain; WWT = weaning weight; PWG = postweaning gain; YWT = yearling weight; $\mathrm{MSC}=$ muscle score; $\mathrm{ASE}$ = average of standard errors for ai.aj, mi.mj, ai.mj, ei.ej, $\mathrm{h}_{\mathrm{t}}^{2}=$ total heritability $=\mathrm{a}^{2}+\mathrm{m}^{2} / 2+1.5\left(\operatorname{cov}_{\mathrm{am}}\right)$.

${ }^{b}$ The i.j $(1,2,3,4,5,6)$ define trait combinations for correlations among a, m, e, or p proportions of phenotypic variance. Additive direct (ai.aj) and phenotypic correlations (pi.pj) are below diagonals. Maternal (mi.mj) and random environmental correlations (ei.ej) are above diagonals.

\section{Genetic and Environmental Variances and Correlations}

Estimates from bivariate analyses of growth characteristics of all animals born in selection and control lines from 1960 through 1985 are presented in Table 6 . The estimates of variances due to direct $\left(\mathrm{a}^{2}\right)$, maternal $\left(\mathrm{m}^{2}\right)$, (with direct-maternal [co]variance [ $\left.\operatorname{cov}_{\mathrm{am}}\right]$ ), common environment of dam $\left(\mathrm{d}^{2}\right)$, and random environment effects $\left(\mathrm{e}^{2}\right)$ are expressed as proportions of phenotypic variance. Total heritability, $\mathrm{h}_{\mathrm{t}}^{2}=\mathrm{a}^{2}+\mathrm{m}^{2} / 2+1.5$ $\left(\operatorname{cov}_{\mathrm{am}}\right)$, represents total additive genetic influence of parents on offspring (Willham, 1972). Estimates of direct-maternal covariance (as a proportion) as well as the correlation $\left(r_{\mathrm{am}}\right)$ are shown because $\mathrm{r}_{\mathrm{am}}$ can be considered a regression coefficient in standard measure and offers a better perspective of change that might result from selection. Correlations are organized according to direct by direct (ai.aj), maternal by maternal (mi.mj), and direct by maternal (ai.mj) for the $i^{\text {th }}$ and $\mathrm{j}^{\text {th }}$ traits. Birth weight, weaning gain, weaning weight, postweaning gain, and yearling weight have part-whole relationships, which aids in interpreting the relative importance of additive direct and maternal components at each growth stage. The phenotypic correlation of weaning gain with weaning weight was 0.9855 , which did not allow partitioning of genetic covariances between the traits.

The additive direct (a), additive maternal (m), and random environmental (e) (co)variances obtained from analyses of carcass records of the 1,503 animals born from 1980 through 1985 are presented in Table 7. Common environmental effects of dams $\left(\mathrm{d}^{2}\right)$ were not significant for any carcass characteristic or market weight and carcass weight and were eliminated from analyses to reduce the number of equations being evaluated. Failure to find variation due to common environmental effects of dams may have been due to the number of years in Sets 1 and 2, and because dams in Set 2 were 
Table 7. Additive direct (a), maternal (m), and environmental (e) proportions of phenotypic (p) variance, and correlations among carcass traits ${ }^{a}$

\begin{tabular}{|c|c|c|c|c|c|c|c|c|c|}
\hline Item & MWT & CWT & REA & MAR & FTH & $\mathrm{KPH}$ & $\mathrm{RPP}$ & MSC & ASE \\
\hline & \multicolumn{9}{|c|}{ Proportion of phenotypic variance } \\
\hline$a^{2}$ & 0.36 & 0.26 & 0.33 & 0.36 & 0.41 & 0.12 & 0.46 & 0.37 & $(0.08)$ \\
\hline $\mathrm{m}^{2}$ & 0.14 & 0.15 & - & 0.07 & 0.05 & 0.08 & 0.05 & 0.14 & $(0.06)$ \\
\hline $\operatorname{Cov}_{\mathrm{am}}$ & 0.022 & 0.005 & - & -0.053 & -0.026 & -0.074 & -0.045 & -0.121 & - \\
\hline $\mathrm{h}_{\mathrm{t}}^{2}$ & 0.46 & 0.34 & 0.31 & 0.31 & 0.40 & 0.05 & 0.42 & 0.26 & - \\
\hline \multirow[t]{2}{*}{$\mathrm{e}^{2}$} & 0.48 & 0.59 & 0.69 & 0.63 & 0.57 & 0.88 & 0.53 & 0.61 & $(0.07)$ \\
\hline & $\begin{array}{c}1 \\
\text { mi.m1 }\end{array}$ & $\begin{array}{c}2 \\
\text { mi.m2 }\end{array}$ & $\begin{array}{c}3 \\
\text { mi.m3 }\end{array}$ & $\begin{array}{c}4 \\
\text { mi.m4 }\end{array}$ & $\begin{array}{c}5 \\
\text { mi.m5 }\end{array}$ & $\begin{array}{c}6 \\
\text { mi.m6 }\end{array}$ & $\begin{array}{c}7 \\
\text { mi.m7 }\end{array}$ & $\begin{array}{c}8 \\
\text { mi.m8 }\end{array}$ & $\begin{array}{l}\text { ASE } \\
\text { mi.mj }\end{array}$ \\
\hline 1. MWT a1.aj & - & 0.97 & - & 0.30 & 0.61 & 0.93 & -0.85 & 0.66 & $(0.74)$ \\
\hline 2. CWT a2.aj & 0.95 & - & - & 0.12 & 0.58 & 0.89 & -0.74 & 0.70 & $(0.71)$ \\
\hline 3. REA a3.aj & 0.22 & 0.25 & - & - & - & - & - & - & - \\
\hline 4. MAR a4.aj & -0.08 & -0.09 & -0.23 & - & 0.16 & 0.59 & -0.56 & -0.45 & $(0.77)$ \\
\hline 5. FTH a5.aj & -0.10 & 0.08 & -0.38 & 0.23 & - & 0.44 & -0.96 & -0.45 & (1.01) \\
\hline 6. KPH a6.aj & -0.01 & -0.02 & -0.60 & 0.39 & 0.52 & - & -0.47 & 0.31 & $(0.80)$ \\
\hline 7. RPP a7.aj & 0.16 & 0.05 & 0.54 & -0.65 & -0.86 & -0.62 & - & 0.54 & $(1.15)$ \\
\hline \multirow{3}{*}{$\begin{array}{l}\text { 8. MSC a8.aj } \\
\text { ASE ai.aj }\end{array}$} & 0.22 & 0.27 & 0.29 & -0.13 & 0.09 & -0.06 & 0.06 & - & $(0.55)$ \\
\hline & $(0.25)$ & $(0.27)$ & $(0.24)$ & $(0.23)$ & $(0.25)$ & $(0.33)$ & $(0.28)$ & $(0.21)$ & - \\
\hline & ai.m1 & ai.m2 & ai.m3 & ai.m4 & ai.m5 & ai.m6 & ai.m7 & ai.m8 & ai.mi \\
\hline 1. MWTa1.mj & 0.10 & 0.07 & - & -0.03 & 0.35 & 0.34 & -0.38 & -0.46 & $(0.41)$ \\
\hline 2. CWT a2.mj & 0.11 & 0.03 & - & 0.16 & 0.48 & 0.40 & -0.64 & -0.55 & $(0.47)$ \\
\hline 3. REA a3.mj & 0.63 & 0.48 & - & 0.45 & 0.49 & 0.61 & -0.63 & 0.00 & $(0.36)$ \\
\hline 4. MAR a4.mj & 0.05 & 0.03 & - & -0.35 & -0.06 & 0.33 & 0.21 & 0.26 & $(0.41)$ \\
\hline 5. FTH a5.mj & 0.08 & -0.06 & - & 0.15 & -0.18 & 0.09 & 0.11 & 0.22 & $(0.40)$ \\
\hline 6. KPH a6.mj & -0.55 & -0.43 & - & -0.57 & 0.04 & -0.76 & 0.18 & 0.18 & $(0.66)$ \\
\hline 7. RPP a7.mj & 0.08 & 0.15 & - & 0.10 & 0.25 & -0.25 & -0.29 & -0.33 & $(0.41)$ \\
\hline \multirow{3}{*}{$\begin{array}{l}\text { 8. MSC a8.mj } \\
\text { ASE ai.mj }\end{array}$} & -0.16 & -0.24 & - & 0.48 & 0.19 & -0.27 & -0.33 & -0.54 & $(0.42)$ \\
\hline & $(0.34)$ & $(0.33)$ & - & $(0.51)$ & $(0.53)$ & $(0.45)$ & $(0.57)$ & $(0.36)$ & $(0.44)$ \\
\hline & ei.e1 & ei.e2 & ei.e3 & ei.e4 & ei.e5 & ei.e6 & ei.e7 & ei.e8 & ei.ej \\
\hline 1. MWT p1.pj & - & 0.94 & 0.42 & 0.25 & 0.40 & 0.23 & -0.37 & 0.38 & $(0.11)$ \\
\hline 2. CWT p2.pj & 0.95 & - & 0.45 & 0.27 & 0.36 & 0.24 & -0.34 & 0.38 & $(0.10)$ \\
\hline 3. REA p3.pj & 0.38 & 0.41 & - & 0.07 & 0.16 & 0.15 & 0.05 & 0.14 & $(0.08)$ \\
\hline 4. MAR p4.pj & 0.14 & 0.16 & 0.00 & - & 0.19 & 0.05 & -0.65 & 0.10 & $(0.09)$ \\
\hline 5. FTH p5.pj & 0.26 & 0.31 & 0.00 & 0.22 & - & 0.19 & -0.82 & 0.20 & $(0.10)$ \\
\hline 6. KPH p6.pj & 0.24 & 0.27 & 0.05 & 0.17 & 0.29 & - & -0.34 & 0.19 & $(0.07)$ \\
\hline 7. RPP p7.pj & -0.20 & -0.25 & 0.19 & -0.65 & -0.84 & -0.43 & - & -0.20 & $(0.12)$ \\
\hline 8. MSC p8.pj & 0.31 & 0.25 & 0.19 & 0.04 & 0.16 & 0.15 & -0.10 & - & $(0.08)$ \\
\hline
\end{tabular}

${ }^{\mathrm{a}} \mathrm{MWT}=$ market weight; CWT $=$ hot carcass weight; REA = longissimus muscle area; MAR = marbling score; FTH = 12th-rib fat thickness; KPH = percentage of kidney, pelvic, and heart fat; RPP = retail product percentage; $\mathrm{MSC}=$ muscle score; $\mathrm{ASE}=$ average of standard errors for ai.aj, mi.mj, ai.mj, or ei.ej, $\mathrm{h}_{\mathrm{t}}^{2}=$ total heritability $=\mathrm{a}^{2}+\mathrm{m}^{2} / 2+1.5\left(\operatorname{cov}_{\mathrm{am}}\right)$.

${ }^{b}$ The i.j $(1,2,3,4,5,6)$ define trait combinations for correlations among a, m, e, or p proportions of phenotypic variance. Additive direct (ai.aj) and phenotypic (pi.pj) correlations are below diagonals. Maternal (mi.mj) and environmental correlations (ei.ej) are above diagonals.

randomized each year to control line sires or to sires of their own line providing for fewer repeated progeny of dams.

Genetic and Environmental Variances of Growth Traits. Total heritability for birth weight, weaning weight, yearling weight, and muscle score (Table 6) was equal to or higher than direct $\left(\mathrm{a}^{2}\right)$ even though $\operatorname{cov}_{\mathrm{am}}$ was negative for weaning weight and muscle score. Maternal effects for yearling weight have not been evaluated as widely as weaning weight because contact with dams is removed at weaning, with maternal influence at later stages of growth considered a carryover effect on postweaning gain. The proportion of phenotypic variance due to common environment of dam $\left(\mathrm{d}^{2}\right)$ for wean- ing weight (0.26) was greater than that due to direct or maternal genetic effects and was much greater than $\mathrm{d}^{2}$ for birth weight (0.02) or yearling weight (0.05).

Estimates in Table 6 compare reasonably well with the weighted averages of published estimates reported by Koots et al. $(1994 a, b)$ for $\left(a^{2}, m^{2}, r_{a m}\right)$, which were BWT $(0.31,0.14,-0.35)$; WWT $(0.24,0.13,-0.16)$; and YWT $(0.35,0.11,-)$. Comparable estimates for Hereford cattle reported by Meyer (1992) and Waldron et al. (1993) using similar animal models and methodology were BWT $(0.41,0.08,0.04)$ and $(0.24,0.11,0.37)$; WWT $(0.14,0.13,-0.59)$ and $(0.15,0.14,-0.35)$; YWT $(0.16$, $0.11,-0.48)$ and $(0.28,0.01,0.97)$; respectively (the value of 0.97 for $r_{a m}$ is exaggerated by the small value 
of $\mathrm{m}^{2}$ ). Estimates from Australian and New Zealand Angus lines selected for yearling gain or weight for $\mathrm{a}^{2}$, $\mathrm{m}^{2}, \mathrm{r}_{\mathrm{am}}$ (Meyer, 1992; Waldron et al., 1993) were BWT $(0.36,0.07,0.28)$ and $(0.33,0.04,0.28)$; WWT $(0.20$, $0.14,0.22)$ and $(0.14,0.11,-0.35)$; YWT $(0.33,0.04,0.49)$ and $(0.30,0.08,0.04)$; respectively.

Genetic Correlations. Correlations (Table 6) among direct (ai.aj) or among maternal effects (mi.mj) indicate positive association of direct or maternal genetic influence at successive stages of growth except for maternal effects between weaning weight and postweaning gain.

Correlations between direct and maternal effects (ai.mj) for growth from birth to yearling age present a contrasting situation. Correlations below the diagonal, where direct genotypes of birth weight, weaning gain, or weaning weight were correlated with subsequent maternal genotypes, were positive. Correlations above the diagonal, where maternal genotypes ( $\mathrm{m} 1$ to $\mathrm{m} 4$ ) were correlated with subsequent direct genotypes (a2 to a5), were negative except for those involving postweaning gain.

Compensation of maternal effects of birth weight or weaning weight on gains to weaning or yearling weight was also evident in the partitioning of variation in direct and maternal effects in Table 3 for YWL and IXL. Correlations do not imply cause and effect but do indicate the direction of genetic or compensatory growth at each stage.

Direct, maternal, direct by maternal, and phenotypic correlations among 1) BWT, 2) WWT, and 3) YWT from the Australian selection experiment (Meyer, 1994) were BWT $\times$ WWT (a1.a2) 0.76, (m1.m2) 0.30, (a1.m2) 0.29, (a2.m1) 0.35, (p1.p2) 0.51; BWT $\times$ YWT (a1.a3) 0.70, (m1.m3) -0.13, (a1.m3) 0.09, (a3.m1) 0.72, (p1.p3) 0.45; and WWT $\times$ YWT (a2.a3) 0.70, (m2.m3) 0.99, (a2.m3) -0.01, (a3.m2) 0.14, (p2.p3) 0.74, respectively. Differences in estimates from that and this experiment could be associated with breeds, seasonality of pasture or feeding conditions, or sampling errors. Meyer reported differences in estimates from Zebu crosses, which were attributed to breeds or temperate and tropical climates in Australia.

Correlations of muscle score direct (a4.aj) or maternal (mi.m4) with other traits were positive. Correlations of muscle score direct with maternal effects of other traits were negative except for correlations with postweaning gain and yearling weight maternal.

Correlations among traits for common environmental effects of dams $\left(d^{2}\right)$ are not shown but were 0.90 or higher for all trait combinations, except birth weight with weaning gain, weaning weight, yearling weight, and muscle score, $0.31,0.34,0.12$, and 0.5 , respectively. The large correlations among other traits (0.90 to 1.00) were magnified by low values of $\mathrm{d}^{2}$.

Phenotypic and Random Environmental Variances. Random environmental effects $\left(\mathrm{e}^{2}\right)$ accounted for 40 to $63 \%$ of the phenotypic variance (Table 6). All random environmental and phenotypic correlations among growth at various stages were positive. The highest environmental correlations were among weaning gain, weaning weight, or postweaning gain with yearling weight. The lowest environmental correlations involved birth weight with muscle score, weaning gain or weaning weight with postweaning gain.

Genetic and Environmental (Co)Variances Among Carcass Traits. The influence of dam on offspring during gestation and the mothering environment from birth to weaning may involve characteristics other than growth and weights at and from birth, weaning, or market stages (Table 7). Physiological effects in utero could also influence the development of muscle or fat growth, such as fat at external and intra- or intermuscular sites at later stages of growth. Although variation due to direct and maternal effects for carcass characteristics is discussed, the large standard errors of these estimates, as reported in Table 8, should be noted.

Additive direct genetic effects formed a large proportion of phenotypic variation for all traits, except for estimated percentage of kidney, pelvic, and heart fat. Maternal effects on carcass characteristics were much less important than direct effects and were larger for market and carcass weights $(0.14$ and 0.15$)$ than for traits associated with carcass composition (0.05 to 0.08 ).

Additive direct heritabilities in Table 7 for carcass weight (0.26), longissimus muscle area (0.33), marbling (0.36), fat thickness $(0.41)$, and retail product percentage (0.46) were within the range of reports by Koots et al. (1994a), Marshall (1994), Gregory et al. (1995), Wilson et al. (1993), and Reverter et al. (2003), who reported, respectively, the following: CWT $(0.23,0.41$, $0.23,0.31,0.39)$; REA $(0.42,0.37,0.22,0.32,0.30)$; MAR $(0.38,0.35,0.48,0.26,0.17)$; FTH $(0.44,0.44,0.25,0.26$, $0.27)$; and $\operatorname{RPP}(0.55,0.36,0.47,-, 0.57)$. The estimates for retail product percentage reported by Gregory et al. (1995) and Reverter et al. (2003) were derived from detailed carcass cutout data. Heritability of kidney, pelvic, and heart fat in Table 7 (0.12) was much lower than reports by Veseth et al. (1993) and Pariacote et al. (1998): 0.37 and 0.45, respectively. Direct and maternal heritabilities reported by Crews and Kemp (1999) were, respectively, carcass weight $(0.30,0.00)$; fat thickness $(0.25,0.09)$; longissimus muscle area $(0.24,0.06)$; and lean yield percentage $(0.25,0.08)$.

Random environmental effects $\left(\mathrm{e}^{2}\right)$ accounted for 48 to $88 \%$ of the phenotypic variance for the carcass traits.

Correlations. Additive direct genetic effects were associated with a large proportion of the phenotypic variation for all traits, except for estimated kidney, pelvic, and heart fat (Table 7). The pattern for estimates of direct genetic correlations for (ai.aj) pairs of traits seems to follow their association with lean or fat growth. The positive correlation of fat thickness with carcass weight (0.08) and the negative correlation with market weight $(-0.10)$ were likely related to an increase in dressing percentage as fat thickness increases $(0.093 \%$ / $\mathrm{mm}$ ). Direct genetic effects for muscle score direct were positively related to all traits except marbling and percentage of kidney, pelvic, and heart fat. 
Table 8. Standard errors of heritabilities and correlations in Table 7

\begin{tabular}{lcccccccc}
\hline \hline Item & MWT & CWT & REA & MAR & FTH & KPH & RPP & MSC \\
\hline ai.ai & 0.09 & 0.08 & 0.09 & 0.09 & 0.09 & 0.06 & 0.10 & 0.09 \\
mi.mi & 0.06 & 0.06 & - & 0.06 & 0.06 & 0.06 & 0.06 & 0.07 \\
ei.ei & 0.07 & 0.06 & 0.07 & 0.07 & 0.07 & 0.05 & 0.08 & 0.07 \\
& mi.m1 & mi.m2 & mi.m3 & mi.m4 & mi.m5 & mi.m6 & mi.m7 & mi.m8 \\
1. MWT a1.aj & & 0.84 & - & 0.56 & 0.75 & 0.78 & 0.95 & 0.54 \\
2. CWT a2.aj & 0.52 & & - & 0.49 & 0.75 & 0.75 & 0.89 & 0.56 \\
3. REA a3.aj & 0.21 & 0.24 & & - & - & - & - & - \\
4. MAR a4.aj & 0.18 & 0.20 & 0.20 & & 0.83 & 0.86 & 1.36 & 0.51 \\
5TH a5.aj & 0.18 & 0.20 & 0.21 & 0.20 & & 0.93 & 2.17 & 0.61 \\
6. KPH a6.aj & 0.27 & 0.29 & 0.36 & 0.34 & 0.38 & & 0.98 & 0.48 \\
7. RPP a7.aj & 0.17 & 0.19 & 0.25 & 0.33 & 0.41 & 0.44 & & 0.59 \\
8. MSC a9.aj & 0.21 & 0.24 & 0.21 & 0.19 & 0.18 & 0.26 & 0.17 & \\
& ai.m1 & ai.m2 & ai.m3 & ai.m4 & ai.m5 & ai.m6 & ai.m7 & ai.m8 \\
1. MWTa1.mj & 0.28 & 0.27 & - & 0.27 & 0.49 & 0.28 & 0.55 & 0.39 \\
2. CWT a2.mj & 0.30 & 0.32 & - & 0.50 & 0.56 & 0.45 & 0.69 & 0.44 \\
3. REA a3.mj & 0.32 & 0.28 & - & 0.41 & 0.43 & 0.37 & 0.46 & 0.25 \\
4. MAR a4.mj & 0.31 & 0.31 & - & 0.58 & 0.48 & 0.37 & 0.53 & 0.32 \\
5TH a5.mj & 0.31 & 0.31 & - & 0.43 & 0.57 & 0.37 & 0.51 & 0.30 \\
6. KPH a6.mj & 0.40 & 0.52 & - & 0.80 & 0.64 & 0.93 & 0.73 & 0.44 \\
7. RPP a7.mj & 0.31 & 0.31 & - & 0.44 & 0.58 & 0.34 & 0.34 & 0.31 \\
8. MSC a9.mj & 0.32 & 0.33 & - & 0.47 & 0.49 & 0.44 & 0.48 & 0.46 \\
& ei.e1 & ei.e2 & ei.e3 & ei.e4 & ei.e5 & ei.e6 & ei.e7 & ei.e8 \\
1. MWT & & 0.21 & 0.10 & 0.09 & 0.10 & 0.07 & 0.10 & 0.10 \\
2. CWT & & & 0.10 & 0.08 & 0.10 & 0.07 & 0.09 & 0.09 \\
3. REA & & & & 0.07 & 0.07 & 0.05 & 0.08 & 0.08 \\
4. MAR & & & & & 0.09 & 0.06 & 0.16 & 0.07 \\
5TH FT & & & & & & 0.07 & 0.21 & 0.08 \\
6. KPH & & & & & & & 0.09 & 0.06 \\
7. RPP & & & & & & & 0.09 \\
\hline
\end{tabular}

aThe i.j $(1,2,3,4,5,6)$ define trait combinations for correlations among a, m, or e, proportions of phenotypic variance. Additive direct (ai.aj) correlations are below diagonals. Maternal (mi.mj) and environmental correlations (ei.ej) are above diagonals.

Maternal effects on carcass characteristics were much smaller than direct genetic effects but were larger for market weight and carcass weight than for traits involving composition of the carcass. Correlations among maternal effects (mi.mj) were positive except for correlations involving marbling and fat thickness with retail product percentage and with muscle score. The RPP was an estimated function of REA, MAR, FTH, and KPH. Correlations of percentages with other traits are affected by autocorrelation with the denominator $(-)$ or numerator $(+)$ (Pearson, 1897).

Correlations of direct and maternal genetic effects among traits (ai.mj) were positive for most combinations in contrast with the predominantly negative correlations of direct and maternal effects within each trait. Additive direct effects for market weight and carcass weight were negatively correlated with maternal effects for retail product percentage, retail product weight, and muscle score. Correlations of direct effects for longissimus muscle area were positively correlated with maternal effects for all traits, except retail product percentage. Correlations among additive direct effects for kidney, pelvic, and heart fat with maternal effects for other traits were negative except for fat thickness and retail product weight. Correlations of additive direct effects for muscle score with maternal effects for other traits (a9.mi) were negative except for marbling and fat thickness (a9.m4, a9.m5).

Environmental and phenotypic correlations among traits were positive, except for correlations involving retail product percentage or retail product weight, which is a calculated value based on REA, MAR, FTH, and $\mathrm{KPH}$.

Comparisons of correlations in Table 7 with other studies is complicated by a lack of published estimates that included maternal effects. In the present study, results for direct by direct (ai.aj) genetic correlations may be influenced by simultaneous allocation of total genetic variation to 10 portions instead of 3 , as in sire models, for each pair of traits. Estimates of additive direct correlations among CWT, REA, MAR, FTH, and RPP reported by Koots et al., (1994b), Marshall (1994), Gregory et al. (1995), Wilson et al. (1993), and Reverter et al. (2003) were CWT with REA (0.47, 0.48, 0.66, 0.47, $0.45)$, MAR (0.10, 0.16, 0.31, -0.06, -0.14), FTH (0.38, $0.39,0.13,0.38,-0.13)$, and RPP $(0.12,-0.11,(0.12,-$, $0.06)$; REA with MAR $(-0.23,-0.14,-0.02,-0.04,-0.14)$, FTH $(-0.08,-0.13,-0.06,-0.13,-0.13)$, and RPP $(0.26$, $0.53,0.32,-, 0.44)$; MAR with FTH $(0.36,0.37,0.44$, $-0.13,0.12)$, and RPP $(-0.54,-0.22,-0.60,-,-0.39)$; 
and FTH with RPP $(-0.33,-0.74,-0.76,-,-0.65)$, respectively. The estimates of correlations in Table 7 tend to be slightly lower than the average of the five sources cited. Sampling variances of the estimates could easily account for the differences, but the model also seems likely to have had some influence on the differences in the estimates.

\section{General Discussion}

Growth Characteristics. When the final phase of the experiment was proposed, statistical methodology and computer capabilities were not available to provide the statistical evaluations of direct and maternal differences that are now available with REML applied to animal models. Therefore, the experiment was designed to study whether maternal genetic effects were of importance in growth characteristics of selected lines. Estimates in Tables 3, 4, and 5 provide some answers to these questions. Tables 6 and 7 provide additional statistical information from an animal model analysis of direct and maternal genetic effects on growth and carcass characteristics. Generally, additive direct genetic effects contributed much more to genetic response and accounted for a greater proportion of the phenotypic variance in growth and carcass traits than did additive maternal genetic effects. Large standard errors of estimates of direct and maternal effects limit confidence on the discussion of differences in maternal effects among lines noted in Tables 3, 4, and 5.

Genetic expectations of maternal contrasts provide some insight into biological reasons for differences observed. For example, the expectation of YWL - CTL from Table 1, assuming heterosis of reciprocal crosses did not differ, was YWL maternal $=\mathrm{m}_{22}-\mathrm{m}_{44}+0.5\left[\left(\mathrm{a}_{24}\right.\right.$ $\left.\left.+\mathrm{a}_{22}\right)^{22}-\left(\mathrm{a}_{22}+\mathrm{a}_{24}\right)^{24}\right]$; superscripts indicate the maternal environment under which direct effects are expressed. Differences in maternal environment of lines can affect the expression of direct effects of sires and dams. In line crosses, sires express their direct effects under the maternal environment of CTL. This could contribute to the differences observed in partitioning estimates into direct, maternal, and heterosis effects. For example, results from Table 3 of Koch et al. (1995) showed direct effects of selection lines differed in expression when evaluated in Hereford (HCM) or in Angus (ACM) crosses. The direct effects of weaning gain and postweaning gain of WWL, YWL, and IXL evaluated from crosses with CTL (HCM) were 6.4, 5.6, and $8.0 \mathrm{~kg}$, and $24.4,23.0$, and 41.2 , respectively. The direct effects of weaning gain and postweaning gain of WWL, YWL, and IXL evaluated from crosses with Angus (ACM) were 3.1, 7.7, and $3.7 \mathrm{~kg}$, and 7.8, 34.1, and 32.1, respectively. Animals that differ in genetic potential but limited in expression of their potential at one stage of growth due to environmental conditions will tend to compensate during subsequent stages of growth if environmental conditions become more favorable. A plausible explanation for compensatory effects of pre- and postweaning gain expressed in YWL and IXL is that YWL calves had a high growth potential but poor maternal environment to weaning. The IXL calves had high growth potential and good maternal environment that may have resulted in a more aggressive postweaning appetite for YWL than for IXL and WWL, which had better maternal environments through weaning. Postweaning, when given ad libitum access to highenergy feed, YWL calves maintained a high feed intake and had the growth potential to use it effectively. A statistical point of importance is that the sum of direct and maternal response in this experimental design is constrained to differences among selected lines when crossed with the control line.

During the 20 yr of selection, energy intake available to animals was generally much more limited during the preweaning period than during the postweaning. Most of the total genetic response from selection in all three lines was associated with direct genetic effects and the highest proportion of gain was from direct genetic effects for postweaning gain. Analyses of Koch et al. (1994) indicated a negative genetic covariance between direct and maternal effects for weaning gain and postweaning gain for each selected line. The selection criterion of yearling weight for YWL, where most of the total gain came from postweaning gain, may have been an important factor in the poor maternal response up to weaning by that line.

The greater total response to selection by the IXL relative to the YWL for market weight and carcass weight (Table 3) is difficult to explain considering the heritability estimates for YWT and MSC and the relatively low estimate of the direct genetic correlation, 0.17 , between YWT and MSC (Table 6). Selection theory would suggest single-trait selection should be more effective than two-trait selection, unless the two traits are strongly correlated. Similar results were reported (Koch et al., 1994) before selection was relaxed in this final phase of the experiment. Inclusion of muscling score as well as yearling weight had more favorable response than would have been expected. It is possible that the addition of muscle score had benefits somewhat like the use of a repeated record or that the "best-doing" animals tended to rank well in all three traits (WWT, YWT, and MSC). While scoring the animals, it was observed that animals with the higher muscling scores not only showed greater expression of musculature, but also tended to have a healthier appearance. We frequently noticed during scoring that the bulls and heifers with higher muscling scores and heavier weights tended to shed their long winter hair coats earlier in the spring than those with lower weights and muscling scores. Perhaps continued selection pressure on muscle score as well as yearling weight over the 20-yr period increased the frequency of favorable alleles at multiple loci more effectively than single-trait selection. Also, selection for the two traits may have resulted in more favorable epistatic combinations of genes than singletrait selection. However, results in the final phase, 
when selection was relaxed in all lines, indicated little or no slippage in selection response (Koch et al., 1994, 1995). Another possibility is that genetic drift was more favorable in the IXL than in the YWL.

Carcass Characteristics. Comparisons of IXL with YWL indicate that selection for the combination of yearling weight and muscle score resulted in small, favorable improvement to carcasses as follows: larger longissimus muscle area, more marbling, lower fat thickness, higher retail product percentage and weight, and lower fat trim percentage and weight. However, comparisons of WWL with YWL were similar or intermediate to those for IXL with YWL. Note in Table 3 that total response in IXL was greatly enhanced by its preweaning maternal component of growth. This suggests the importance of weaning and postweaning performance to optimize desirable carcass development. Thus, the improvement in IXL over YWL may have been due to enhancement from maternal gains to weaning as well as muscularity per se.

The most notable indirect effects of selection over the $20 \mathrm{yr}$ on carcass characteristics were increased weight of carcass with more weight of lean meat at the same age and produced with less feed per unit of gain. The marbling score of selected lines differed from CTL by only $\pm 10 / 100$ of a degree. At the same carcass weight, selected lines had 1.32 to $1.85 \%$ more retail product and 1.62 to $2.24 \%$ less fat trim with only $10 / 100$ to 25/100 degrees less marbling than CTL. Concern was expressed about possible loss of marbling associated with selection for increased rate of gain from analyses of carcass cutout data obtained from 377 animals in the experiment that were born from 1963 through 1970 (Koch, 1978). Even though the direct genetic correlations (ai.aj) of MAR with MWT, CWT, RPP, RPW, and MSC were -0.08 . $-0.09,-0.65,-0.49$, and -0.13 , respectively, $20 \mathrm{yr}$ of selection for increased rate of gain did not result in a serious loss of marbling but did increase the amount of beef to be sold.

The results did indicate that selection based on criteria that increased maternal ability at weaning and at yearling age; i.e., responses in IXL and WWL resulted in a more desirable marbling response than that observed in the YWL.

\section{Implications}

Steady and significant progress can be achieved in closed herds maintained with annual use of only six bulls and 150 cows by selection of beef animals with superior records of performance for moderately heritable traits. Selection emphasis on both direct and maternal components of growth is superior to emphasis on the direct component alone. Selection for two traits does not necessarily decrease the rate of progress relative to selection for one of the two traits, provided that traits share a favorable genetic correlation. Selection for growth in weight alone is not sufficient to optimize genetic progress in beef cattle. Other traits, such as carcass and meat characteristics, should also be considered. Even greater progress in herds could be expected by using the records of performance and expected progeny differences from many herds that share common ancestors.

\section{Literature Cited}

Arthur, P. F., P. F. Parnell, and E. C. Richardson. 1997. Correlated responses in calf body weight and size to divergent selection for yearling growth rate in Angus cattle. Livest. Prod. Sci. 49:305-312.

Baker, R. L., C. A. Morris, D. L. Johnson, J. C. Hunter, and S. M. Hickey. 1991. Results of selection for yearling or 18-month weight in Angus and Hereford cattle. Livest. Prod. Sci. 29:277-296.

Boldman, K. G., L. A. Kriese, L. D. Van Vleck, C. P. Van Tassell, and S. D. Kachman. 1995. A Manual for Use of MTDFREML: A Set of Programs to Obtain Estimates of Variances and Covariances [Draft]. USDA-ARS, Washington, DC.

Buchanan, D. S., M. K. Nielsen, R. M. Koch, and L. V. Cundiff. 1982a. I. Selection for growth and muscling score in beef cattle. I. Selection applied. J. Anim. Sci. 55:516-525.

Buchanan, D. S., M. K. Nielsen, R. M. Koch, and L. V. Cundiff. 1982b. Selection for growth and muscling score in beef cattle. II. Genetic parameters and predicted response. J. Anim. Sci. 55:526-532.

Crews, D. H. Jr., and R. A. Kemp. 1999. Contributions of preweaning growth information and maternal effects for prediction of carcass trait breeding values among crossbred beef cattle. Can. J. Anim. Sci. 79:17-25.

Cundiff, L. V., R. M. Koch, K. E. Gregory, and G. M. Smith. 1981. Characterization of biological types of cattle-Cycle II. IV. Postweaning growth and feed efficiency of steers. J. Anim. Sci. $53: 332-346$

Dodenhoff, J., L. D. Van Vleck, S. D. Kachman, and R. M. Koch. 1998. Parameter estimates for direct, maternal and grandmaternal genetic effects for birth weight and weaning weight in Hereford cattle. J. Anim. Sci. 76:2521-2527.

Graser, H.-U., S. P. Smith, and B. Tier. 1987. A derivative-free approach for estimating variance components in animal models by restricted maximum likelihood. J. Anim. Sci. 64:1362-1370.

Gregory, K. E., L. V. Cundiff, and R. M. Koch. 1995. Genetic and phenotypic (co)variances for growth and carcass traits of purebred and composite populations of beef cattle. J. Anim. Sci. 73:1920-1926.

Herd, R. M. 1990. The direct and maternal components of the response to divergent selection for yearling growth rate in Angus cattle. Anim. Prod. 51:505-513.

Klosterman, E. W., L. G. Sanford, and C. F. Parker. 1968. Effect of cow size and condition and ration protein content upon maintenance requirements of mature beef cows. J. Anim. Sci. 27:242-246.

Koch, R. M. 1978. Selection in beef cattle. III. Correlated response of carcass traits to selection for weaning weight, yearling weight and muscle score in cattle. J. Anim. Sci. 47:142-150.

Koch, R. M., L. V. Cundiff, and K. E. Gregory. 1994. Cumulative selection and genetic change for weaning or yearling weight or for yearling weight plus muscle score in Hereford cattle. J. Anim. Sci. 72:864-885.

Koch, R. M., L. V. Cundiff, and K. E. Gregory. 1995. Direct and maternal responses to selection for weaning or yearling weight or for yearling weight and muscle score in Hereford cattle. J. Anim. Sci. 73:2951-2958.

Koch, R. M., K. E. Gregory, and L. V. Cundiff. 1974a. Selection in beef cattle. I. Selection applied and generation interval. J. Anim. Sci. 39:449-458.

Koch, R. M., K. E. Gregory, and L. V. Cundiff. 1974b. Selection in beef cattle. II. Selection response. J. Anim. Sci. 39:459-470.

Koch, R. M., K. E. Gregory, and L. V. Cundiff. 1982. Critical analysis of selection methods and experiments in beef cattle and conse- 
quences upon selection programs applied. Proc. 2nd World Cong. Genet. Appl. Livest. Prod. 5:514-526.

Koots, K. R., J. P. Gibson, C. Smith, and J. W. Wilton. 1994a. Analyses of published genetic parameter estimates for beef production traits. 1. Heritability. Anim. Breed. Abstr. 62:309-338.

Koots, K. R., J. P. Gibson, and J. W. Wilton. 1994b. Analyses of published genetic parameter estimates for beef production traits. 2. Phenotypic and genetic correlations. Anim. Breed. Abstr. 62:825-853.

Marshall, D. M. 1944. Breed differences and genetic parameters for body composition traits in beef cattle. J. Anim. Sci. 72:27452755.

Meyer, K. 1992. Variance components due to direct and maternal effects for growth traits of Australian beef cattle. Livest. Prod. Sci. 31:179-203.

Meyer, K. 1994. Estimates of direct and maternal correlations among growth traits in Australian beef cattle. Livest. Prod. Sci. 38:91-105.

Morris, C. A., R. L. Baker, and J. C. Hunter. 1992. Correlated responses to selection for yearling or 18-month weight in Angus and Hereford cattle. Livest. Prod. Sci. 30:33-52.

Morris, C. A., R. L. Baker, J. J. Bass, K. R. Jones, and J. A. Wilson. 1993. Carcass composition in weight-selected and control bulls from a serial slaughter experiment. Aust. J. Agric Res. 44:199-213.

NRC. 1970. Nutrient Requirements of Domestic Animals, No. 4. Nutrient Requirements of Beef Cattle. 4th rev. ed. Natl. Acad. Sci.Natl. Res. Coun., Washington, DC.

Pariacote, F., L. D. Van Vleck, and R. E. Hunsley. 1998. Genetic and phenotypic parameters for carcass traits of American Shorthorn beef cattle. J. Anim. Sci. 76:2584-2588.
Parnell, P. F., P. F. Arthur, and R. Barlow. 1997. Direct response to divergent selection for yearling growth rate in Angus cattle. Livest. Prod. Sci. 49:305-312.

Pearson, K. 1897. Mathematical contribution to the theory of evolution. On the form of spurious correlations which may arise when indices are used in the measurement of organs. Proc. Royal Soc. London. 60:489-498.

Perry, D., and P. F. Arthur. 2000. Correlated responses in body composition and fat partitioning to divergent selection for yearling growth rate in Angus cattle. Livest. Prod. Sci. 49:305-312.

Reverter, A., D. J. Johnson, D. Perry, M. E. Goddard, and H. M. Burrow. 2003. Genetic and phenotypic characterization of animal, carcass, and meat quality traits from temperate and tropically adapted beef breeds. 2 . Abattoir carcass traits. Aust. J. Agric. Res. 54:119-134.

Shackelford, S. D., L. V. Cundiff, K. E. Gregory, and D. M. Koohmaraie. 1995. Predicting beef carcass cutability. J. Anim. Sci. 73:406-413

Smith, S. P., and H.-U. Graser. 1986. Estimating variance components in a class of mixed models by restricted maximum likelihood. J. Dairy Sci. 69:1156-1165.

Veseth, D. A., W. L. Reynolds, J. J. Urick. T. C. Nelson, R. E. Short, and D. D. Kress. 1993. Paternal half-sib heritabilities and genetic, environmental, and phenotypic correlation estimates from randomly selected Hereford cattle. J. Anim. Sci. 71:1730-1736.

Waldron, D. F., C. A. Morris, R. L. Baker, and D. L. Johnson. 1993. Maternal effects for growth traits in beef cattle. Livest. Prod. Sci. 35:57-70.

Willham, R. L. 1972. The role of maternal effects in animal breeding. III. Biometrical aspects of maternal effects in animals. J. Anim. Sci. 35:1288-1293.

Wilson, D. E., R. L. Willham, S. L. Northcutt, and G. H. Rouse. 1993. Genetic parameters for carcass traits estimated from Angus field records. J. Anim. Sci. 71:2365-2370. 